Original Russian Text (C) 2020 S.A. Ermolov published in Forest Science Issues Vol. 3, No. 3, pp. 1-24

DOI 10.31509/2658-607x-202141d20

\title{
EARTHWORM COMMUNITIES (OLIGOCHAETA, LUMBRICIDAE) OF PINE FORESTS AND SMALL FOLIAGE FORESTS IN THE FOREST-STEPPE OB' REGION
}

\author{
S.A. Ermolov \\ Center for Forest Ecology and Productivity of the Russian Academy of Sciences \\ Profsoyuznaya st. 84/32 bldg. 14, Moscow 117997, Russian Federation \\ E-mail: ermserg96@gmail.com \\ Received 06.04.2020 \\ Accepted 02.06.2020
}

Earthworms form an essential group of soil macrofauna that performs a number of ecosystem functions in forests. Studies of the species composition and population density of earthworms were conducted in many regions of Russia; however, the fauna of Lumbricidae of Novosibirsk area remained unexplored for a long time. The objective of this work is to carry out a comparative analysis of earthworm population in coniferous and small foliage forests of the foreststeppe $\mathrm{Ob}$ region (Novosibirsk area) and to identify the correlation between the fauna composition and the basic physical and chemical properties of the soil. The study was conducted in pine forests and birch-aspen forests. The main method of registration was layer-by-layer excavation of soil with hand sorting of soil samples and analysis of forest deadwood. Some soil parameters were also measured. Data of the species composition and population density of earthworms for each habitat are given. The studied habitats were classified according to the ratio of the earthworm living forms. It was found that soil humidity is the most significant factor for the group of epigeic and epiendogeic species. The diversity of epigeic and epi-endogeic earthworm species in forests is largely supported by deadwood. The Asian subspecies Eisenia nordenskioldi nordenskioldi was subjected to morphometric analysis confirming its characteristic polymorphism.

Key words: earthworms, living forms, Eisenia nordenskioldi nordenskioldi, Novosibirsk area, small foliage forests, deadwood, soil properties

In forest ecosystems, earthworms form one of the most important groups of soil-forming animals. As saprophages, earthworms of different species and living forms to varying degrees contribute to transformation of organic matter: epigeic and epi-endogeic earthworms decompose plant remains, thereby supporting the formation of the humus horizon; anecic earthworms help the organic matter to penetrate into the deep layers of soil; endogeic earthworms living at different depths consume humus, thus carrying out mineralization of organic matter and transfer of $\mathrm{C}$ and $\mathrm{N}$ compounds in the soil
(Perel', 1975; 1979; Holdsworth et al., 2008). The presence of various species and living forms of earthworms, as well as their estimated population density, indicate the state of forest soils (Chekanovskaja, 1960; Akkumuljacija..., 2018).

Soil is not the only habitat for earthworms. They also inhabit forest litter, live in piles of animal dung, and are abundant in deadwood, contributing to its destruction. The latter is most important for forest ecosystems, where deadwood helps to maintain not only the species diversity, but also the functional 
diversity of earthworms (Geraskina, 2016b, 2016c; Ashwood et al., 2019).

Studies of earthworms in forest ecosystems have been conducted in many regions of Russia. The territory of the Russian Plain, the Urals, the Northwestern and Central Caucasus, and the Far East were studied in more detail (Perel', 1958; Penev et al., 1994; Shashkov, 2003; Rapoport, 2010; Ganin, 2013). In Western Siberia, the forests of Altai and Mountain Shoriya have been studied (Perel', 1994; Musienko, 2019), whereas in the territory of Novosibirsk area, in particular in the area of the forest-steppe $\mathrm{Ob}$ region, which comprises a variety of forest landscapes (Mugako, 2008; Atlas..., 2002), such studies are virtually non-existent. Since studying of the biotopic distribution and molecular genetic diversity of earthworms (Shehovcov et al., 2016; Kim-Kashmenskaja, 2016; Ermolov, 2018, 2018a, 2019; Shehovcov et al., 2020) has recently begun in this region, we decided to contribute to this research by studying the forest ecosystems of the forest-steppe $\mathrm{Ob}$ region, Novosibirsk area.

The objective of this work is to conduct a comparative analysis of the earthworm population of coniferous and small foliage forests of the forest-steppe $\mathrm{Ob}$ region of Novosibirsk area and to identify the relationship of its composition with the main environmental factors.

\section{Tasks:}

1. To compare the species composition and complexes of earthworms living forms (Lumbricidae) in coniferous (pine forests) and small foliage (birch-aspen) forests.

2. To study the earthworm population of forest deadwood as a specific habitat of soil saprophages.

3. To investigate the relationship between the species composition of earthworms and the main physical and chemical properties of forest soils.

4. To provide rationalization for distinguishing between large-sized and smallsized earthworms of the Eisenia nordenskioldi nordenskioldi subspecies according to their external morphological features.

\section{MATERIAL AND METHODS}

Research area. Novosibirsk area is traditionally divided into five natural and geographical regions: Vasyuganye, Baraba, Kulunda, Ob region, and Salair (Mugako, 2008; Atlas..., 2002). The territory of the forest-steppe $\mathrm{Ob}$ region includes typical meadow-steppe landscapes and mixed-herb forests as well as small foliage (birch-aspen) herb forests on sod-podzolic and gray forest soils (Atlas..., 2002), where the material for the study was sampled. Samplings were carried out in tall-herb-fern pine forests (Zael'covskij, Kudrjashovskij, Chemskoj, pine forests in the vicinity of Baryshevo village and Sosnovka settlement); in birch-aspen forests: tall-herb-fern birch-aspen forests (in the vicinity of Bykovo village, Morozovo and Kol'covo settlements), tall-herb-goutweed birch forest (in the vicinity of Shelkovichiha station), low-herb birch forest (in the vicinity of Verh-Tula village). The following types of soils were found in the studied territories: sod-low podzolic sandy soils, sod-podzolic and gray forest (mostly dark) soils (Fig. 1) (Pochvennaja karta..., 2007).

Earthworm sampling. Earthworm sampling in the soils involved layer-by-layer excavation of soil with hand sorting (Metody..., 1975). A square $50 \mathrm{~cm}$ sides was marked on the selected plot of forest soil. First, the litter was sorted, then the soil layers with a thickness of $0-2 \mathrm{~cm}, 2-5 \mathrm{~cm}, 5-10 \mathrm{~cm}$ and more than $10 \mathrm{~cm}$ ( up to $40 \mathrm{~cm}$ or deeper) were excavated with subsequent hand sorting. 8 soil pits were taken in each studied forest.

Earthworm sampling in deadwood: the length and diameter of the fallen trunks at decomposition stage 2-3 or their fragments were measured in several places with subsequent hand sorting of the bark, moss cover and rotting wood. If possible, the deadwood was sorted all the way to the ground (Geraskina, 2016b, 2016c).

The collected worms were euthanized in 2 $\%$ formalin solution and fixed in $4 \%$ formalin solution with glycerine (Chekanovskaja, 1960). The species composition of earthworms was determined according to the field guide by T.S. Vsevolodova-Perel' (Vsevolodova-Perel', 1997).

Individuals of the Eisenia nordenskioldi nordenskioldi subspecies, which have characteristic pronounced polymorphism 
(Perel', 1994, 1997), were subjected to morphometric analysis. During the analysis the following parameters (Shehovcov et al., 2020) were measured: segment number (SN), body length (BL, mm), body width at the widest point (BW, mm), clitellum length (CL, $\mathrm{mm})$, clitellum width $(\mathrm{CW}, \mathrm{mm})$, body weight of the worm fixed in formalin solution $(\mathrm{W}, \mathrm{g})$. Since large-sized worms suitable for morphometry (i. e., adult worms with a distinct clitellum) were rare, all the individuals found in pine forests and small foliage forests were divided into two general groups. Small-sized worms were grouped according to specific habitats: two for deadwood (Kol'covo, Bykovo) and one for soil (Verh-Tula), where the number of the subspecies was the highest.

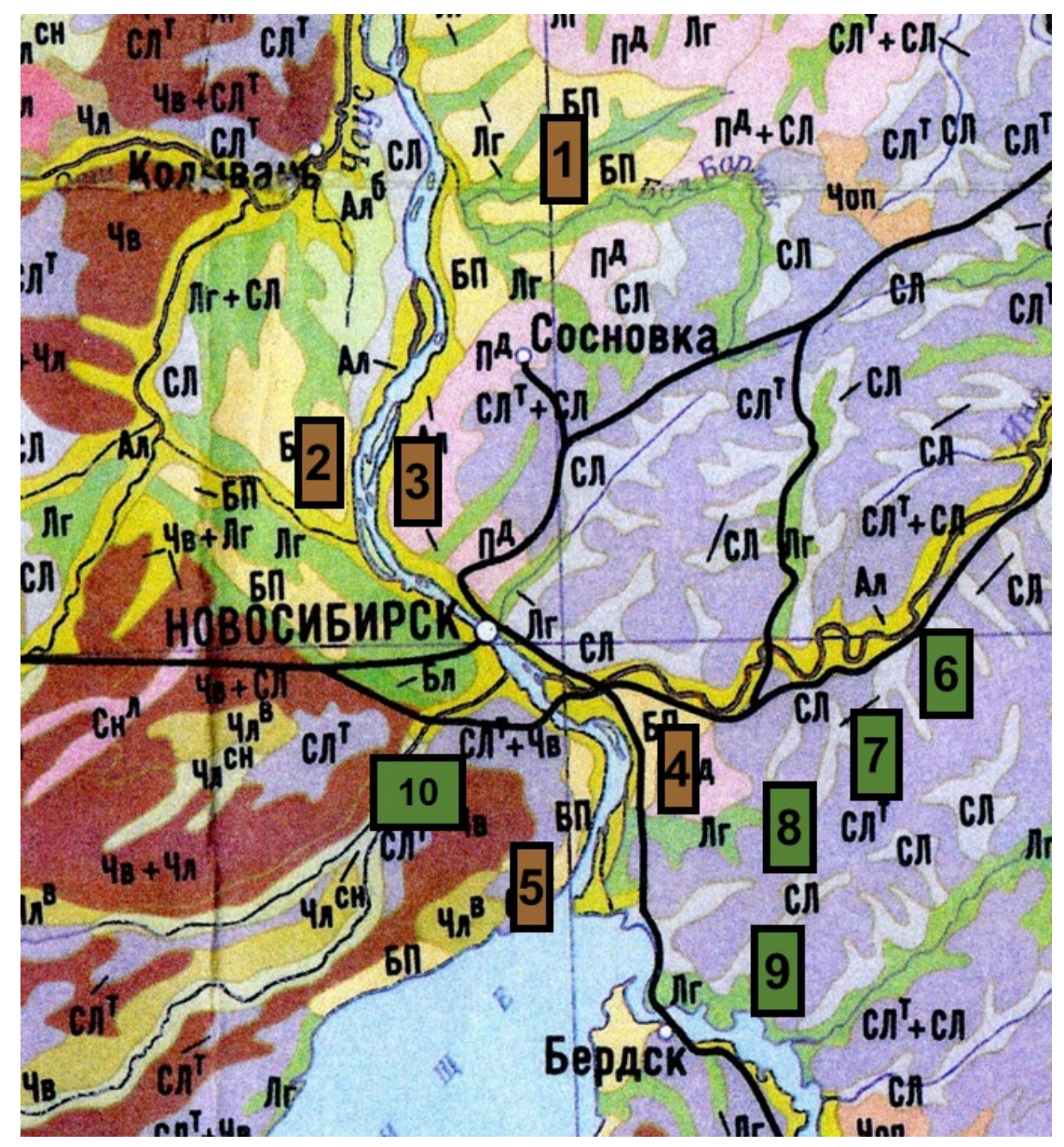

Figure 1. A fragment of the soil map of Novosibirsk area (Pochvennaja karta..., 2007) with the studied pine and small foliage forests

Note. Pine forests: 1 - vicinity of Sosnovka settlement; 2 - Kudrjashovskij pine forest; 3 -Zael'covskij pine forest; 4 - vicinity of Baryshevo village; 5 - Chemskoj pine forest; Small foliage forests in the vicinity of villages: 6 -Shelkovichiha station; 7 - Bykovo village; 8 - Kol'covo settlement; 9 - Morozovo settlement; 10 - Verh-Tula village

The sampling was carried out in the summer of 2019. In total, 80 soil samples were taken during the season, $5.13 \mathrm{~m}^{3}$ of deadwood was sorted, and 3394 individuals of earthworms of various species and living forms were collected.

Soil samples analysis. During earthworm sampling in all the studied habitats, the thickness of the litter and the humus horizon were measured for each soil pit (with an accuracy of $1 \mathrm{~mm}$ ); soil samples were taken from each sample layer $(0-2,2-5,5-10,10$ $30 \mathrm{~cm}$ ) for further laboratory analysis.

Soil humidity (hygroscopic humidity) and acidity (actual acidity, water $\mathrm{pH}$ ) were determined in soil samples. To calculate the moisture content in the soil, fresh wet samples were packed in aluminium cups and weighed, 
then dried to an air-dry state and re-weighed. The percentage of moisture $(W)$ was calculated using the formula:

$$
W=\frac{m_{1}-m_{0}}{m_{0}-m} * 100 \%
$$

Where $m_{1}$ is the mass of wet soil with a cup and a lid, $\mathrm{g} ; m_{0}$ is the mass of dried soil with a cup and a lid, g; $m$ is the mass of an empty cup with a lid, g (GOST 28268-89).

Potentiometric method was used to measure acidity: a suspension was prepared in distilled water from $20 \mathrm{~g}$ of dry soil sample sifted through a fine sieve, and then a MI-150 electrode of the $\mathrm{pH}$ meter was placed into it (Vorob'eva et al., 2012).

Data processing. The obtained data on the population density of earthworms were calculated per unit area for soil samples (individuals $/ \mathrm{m}^{2}$ ), and per unit volume (individuals $/ \mathrm{m}^{3}$ ) for deadwood; the volume of the deadwood was calculated according to the

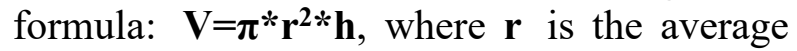
radius of the trunk; and $\mathbf{h}$ is the height of the trunk (Geraskina, 2016b, 2016c).

The Spearman's rank correlation coefficient was used to calculate correlations between the earthworm population density and the physical and chemical properties of the soil.

For each habitat, average data values for soil humidity and acidity were calculated. Average values are also calculated for the litter thickness and the humus horizon thickness. Then the data obtained were compared with the density of the earthworm population in each habitat group. Worms belonging to the main morpho-ecological types were considered separately (Perel', 1975, 1979): worms that feed on the soil surface (epigeic and epi-endogeic) and worms that feed on soil humus (upper-soil-layer and middle-soil-layer endogeic earthworms). The correlation analysis did not take into account the data on the density of endogeic earthworm population in the pine forest in the vicinity of Baryshevo village due to the low density of worms in this group (10 individuals $/ \mathrm{m}^{2}$ ).

Samples with morphometric data of E. nordenskioldi nordenskioldi earthworms were compared using the Mann-Whitney Utest.
Clustering of habitats according to the composition of living forms was performed in the Past software. The initial data were normalized by the dominance index: in all habitats, the population density of earthworms of each living form was calculated as a proportion of the total population. This allowed us to obtain uniform units of measurement. To measure the distance between objects, the Euclidean distance was used, and the Ward's method was used to construct dendrograms (Vjen Rajzin, 1980).

\section{RESULTS}

\section{Earthworm population in pine forests}

In the studied pine forests, both cosmopolitan earthworm species (Dendrobaena octaedra (Savigny, 1826), Lumbricus rubellus (Hoffmeister, 1843), Aporrectodea caliginosa caliginosa (Savigny, 1826), Dendrodrilus rubidus subrubicundus (Eisen, 1874) and worms inhabiting mainly the Asian part of the Russian Federation and adjacent territories (Eisenia nordenskioldi nordenskioldi (Eisen, 1879), Eisenia nordenskioldi pallida Malevič, 1956) were found.

The highest density of earthworm population was observed in the Zael'covskij pine forest $\left(174\right.$ individuals $\left./ \mathrm{m}^{2}\right)$, whereas it was the lowest in the pine forest in the vicinity of Baryshevo village (30 individuals $/ \mathrm{m}^{2}$ ), where worms were not found in all pits, and some species were found only once (Table 1). The most diverse species composition was found in the Kudrjashovskij pine forest (4 subspecies, 2 species; 172 individuals $/ \mathrm{m}^{2}$ in total, some species were found only once), and the least diverse species composition was found in the pine forest in the vicinity of Sosnovka settlement (2 subspecies, 1 species; 124 individuals $/ \mathrm{m}^{2}$ in total), where, with the exception of $D$. octaedra, there were no cosmopolitan species. The Chemskoj pine forest is similar in species composition to the Kudrjashovskij pine forest, and in terms of the population density of worms it is similar to the pine forest in Sosnovka settlement ( 3 subspecies, 2 species; 124 individuals $/ \mathrm{m}^{2}$ in total). In all the studied pine forests, the E. n. nordenskioldi subspecies was represented by both smallsized and large-sized earthworms. 
Table 1. Population of earthworms (Lumbricidae) in pine forests $(X \pm S E)$

\begin{tabular}{|c|c|c|c|c|c|}
\hline $\begin{array}{l}\text { Type of } \\
\text { biotope }\end{array}$ & $\begin{array}{c}\text { Place of } \\
\text { sampling }\end{array}$ & Living forms & Species & $\begin{array}{c}\text { Population } \\
\text { density of the } \\
\text { species, } \\
\text { individuals/m } / \mathbf{m}^{2}\end{array}$ & $\begin{array}{l}\text { Proportion } \\
\text { of the } \\
\text { living } \\
\text { form, } \% \\
\end{array}$ \\
\hline \multirow{29}{*}{ 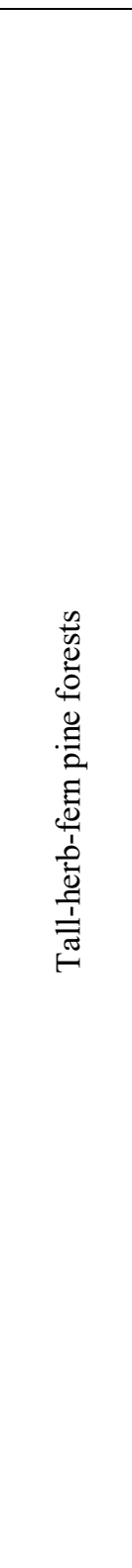 } & \multirow{6}{*}{$\begin{array}{l}\text { Chemskoj pine } \\
\text { forest }\end{array}$} & Epigeic & D. octaedra & $4 \pm 2$ & 3 \\
\hline & & \multirow{3}{*}{ Epi-endogeic } & L. rubellus & $2 \pm 1$ & \multirow{3}{*}{11} \\
\hline & & & E. n. nordenskioldi (small-sized) & $6 \pm 2$ & \\
\hline & & & E. n. nordenskioldi (large-sized) & $6 \pm 2$ & \\
\hline & & \multirow{2}{*}{$\begin{array}{c}\text { Endogeic } \\
\text { (middle-soil-layer) }\end{array}$} & A. c. caliginosa & $84 \pm 23$ & \multirow{2}{*}{86} \\
\hline & & & E.n.pallida & $22 \pm 8$ & \\
\hline & \multirow{7}{*}{$\begin{array}{l}\text { Kudrjashovskij } \\
\text { pine forest }\end{array}$} & \multirow{2}{*}{ Epigeic } & D. octaedra & $16 \pm 3$ & \multirow{2}{*}{11} \\
\hline & & & D. r. subrubicundus & $3 \pm 1$ & \\
\hline & & \multirow{3}{*}{ Epi-endogeic } & Lumbricus rubellus & $1 \pm 1$ & \multirow{3}{*}{10} \\
\hline & & & E. n. nordenskioldi (small-sized) & $11 \pm 3$ & \\
\hline & & & E. n. nordenskioldi (large-sized) & $5 \pm 2$ & \\
\hline & & \multirow{2}{*}{$\begin{array}{c}\text { Endogeic } \\
\text { (middle-soil-layer) }\end{array}$} & A.c. caliginosa & $80 \pm 33$ & \multirow{2}{*}{79} \\
\hline & & & Eisenia nordenskioldi pallida & $57 \pm 20$ & \\
\hline & \multirow{6}{*}{$\begin{array}{l}\text { Zael'covskij } \\
\text { pine forest }\end{array}$} & Epigeic & Dendrobaena octaedra & $14 \pm 8$ & 8 \\
\hline & & \multirow{3}{*}{ Epi-endogeic } & Lumbricus rubellus & $42 \pm 16$ & \multirow{3}{*}{32} \\
\hline & & & E. n. nordenskioldi (small-sized) & $10 \pm 4$ & \\
\hline & & & E. n. nordenskioldi (large-sized) & $4 \pm 1$ & \\
\hline & & Endogeic & A. c. caliginosa & $42 \pm 26$ & \multirow{2}{*}{60} \\
\hline & & (middle-soil-layer) & E.n.pallida & $62 \pm 20$ & \\
\hline & \multirow{4}{*}{$\begin{array}{l}\text { Pine forest in } \\
\text { the vicinity of } \\
\text { Sosnovka } \\
\text { settlement }\end{array}$} & Epigeic & D. octaedra & $16 \pm 7$ & 13 \\
\hline & & \multirow{2}{*}{ Epi-endogeic } & E. n. nordenskioldi (small-sized) & $32 \pm 17$ & \multirow{2}{*}{35} \\
\hline & & & E. n. nordenskioldi (large-sized) & $12 \pm 8$ & \\
\hline & & $\begin{array}{c}\text { Endogeic } \\
\text { (middle-soil-layer) }\end{array}$ & E.n.pallida & $64 \pm 43$ & 52 \\
\hline & \multirow{6}{*}{$\begin{array}{l}\text { Pine forest in } \\
\text { the vicinity of } \\
\text { Baryshevo } \\
\text { village }\end{array}$} & \multirow{2}{*}{ Epigeic } & D. octaedra & $9 \pm 3$ & \multirow{2}{*}{34} \\
\hline & & & D. r. subrubicundus & $1 \pm 1$ & \\
\hline & & \multirow{2}{*}{ Epi-endogeic } & E. n. nordenskioldi (small-sized) & $9 \pm 3$ & \multirow{2}{*}{33} \\
\hline & & & E. n. nordenskioldi (large-sized) & $1 \pm 1$ & \\
\hline & & $\begin{array}{c}\text { Endogeic } \\
\text { (upper-soil-layer) }\end{array}$ & O. lacteum (small-sized) & $4 \pm 4$ & 13 \\
\hline & & $\begin{array}{c}\text { Endogeic } \\
\text { (middle-soil-layer) }\end{array}$ & E. n. pallida & $6 \pm 3$ & 20 \\
\hline
\end{tabular}

According to the ratio of living forms, all the studied pine forests were divided into three groups:

1. pine forests with a predominance (up to $86 \%)$ of middle-soil-layer endogeic earthworms (Chemskoj and Kudrjashovskij pine forests);

2. pine forests, where epigeic and epiendogeic earthworms make up about $50 \%$ of the population (Zael'covskij pine forest and the vicinity of Sosnovka settlement);
3. pine forest, where the ratio of all living forms is approximately the same (the vicinity of Baryshevo village) (Fig. 2; Table 1).

In the Chemskoj and Kudryashovskiy pine forests the species composition, forming complexes of living forms, was almost identical, whereas the Zael'covskij pine forest and the area in the vicinity of Sosnovka settlement revealed significant differences in species composition. Thus, the epi-endogeic earthworms in the Zael'covskij pine forest are 
mainly represented by L. rubellus, while in Sosnovka the only representative of this group is $E$. $n$. nordenskioldi. In the Zael'covskij forest, the middle-soil-layer endogeic earthworms are represented by $A$. $c$. caliginosa and E. n. pallida subspecies (the population density of $A$. c. caliginosa being considerably lower than in the Chemskoj and
Kudrjashovskij pine forests), and in Sosnovka this form is represented only by E. $n$. pallida. In the pine forest in the vicinity of Baryshevo village, singular individuals of the upper-soillayer endogeic Octolasion lacteum (Örley, 1885) was found, and the proportions of other species and living forms were approximately equal.

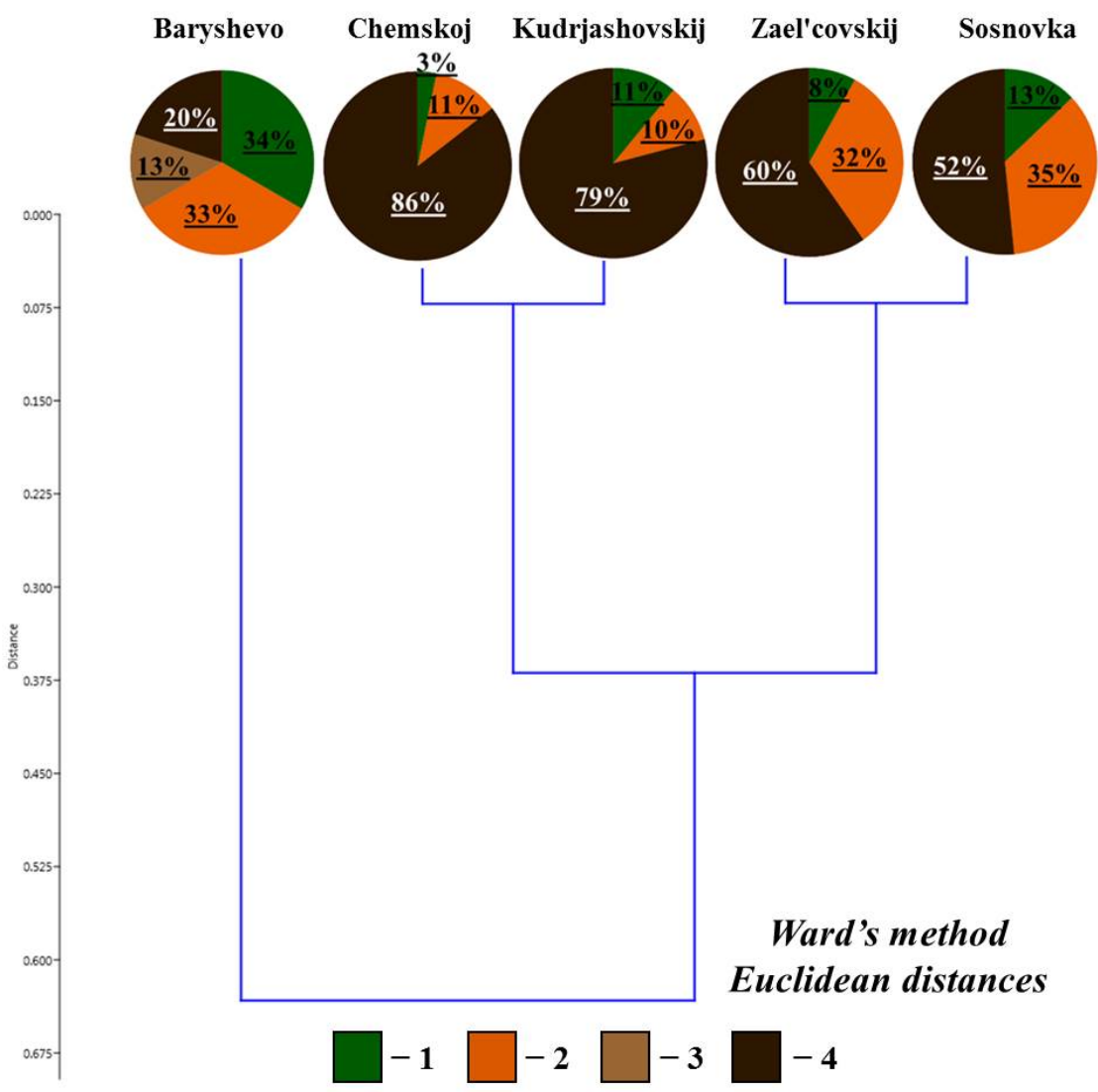

Figure 2. The ratio of living forms of earthworms in pine forests

Note. 1 - epigeic; 2 - epi-endogeic; 3 - upper-soil-layer endogeic; 4 - middle-soil-layer endogeic

In the Chemskoj and Kudryashovskiy pine forests the species composition, forming complexes of living forms, was almost identical, whereas the Zael'covskij pine forest and the area in the vicinity of Sosnovka settlement revealed significant differences in species composition. Thus, the epi-endogeic earthworms in the Zael'covskij pine forest are mainly represented by $L$. rubellus, while in Sosnovka the only representative of this group is $E$. n. nordenskioldi. In the Zael'covskij forest, the middle-soil-layer endogeic earthworms are represented by A. c. caliginosa and E. n. pallida subspecies (the population density of $A$. $c$. caliginosa being considerably lower than in the Chemskoj and Kudrjashovskij pine forests), and in Sosnovka this form is represented only by $E$. n. pallida. In the pine forest in the vicinity of
Baryshevo village, singular individuals of the upper-soil-layer endogeic Octolasion lacteum (Örley, 1885) was found, and the proportions of other species and living forms were approximately equal.

\section{Earthworm population in small foliage forests}

The species composition of earthworms in the studied small foliage forests was generally similar to that in the pine forests (Table 2). High population density of earthworms was observed in two tall-herb-fern birch-aspen forests (in the vicinity of Bykovo village 216 individuals $/ \mathrm{m}^{2}$ and in the vicinity of Morozovo settlement - 263 individuals $/ \mathrm{m}^{2}$ ) and in the tall-herb-goutweed birch forest (in the vicinity of Shelkovichiha station - 267 individuals $/ \mathrm{m}^{2}$ ). The $O$. lacteum species 
(small-sized) was also found in these forests (Shehovcov, Ermolov et al., 2020), its population density being the highest in the forest in the vicinity of Morozovo settlement (202 individuals $/ \mathrm{m}^{2}$ ).

In the tall-herb-fern birch-aspen forest in the vicinity of Kol'covo settlement and in low-grass birch forest in the vicinity of VerhTula village, the population density of earthworms was significantly lower (Kol'covo - 55 individuals $/ \mathrm{m}^{2}$, Verh-Tula - 72 individuals $/ \mathrm{m}^{2}$ ). Noteworthy is also low species diversity: only E. n. nordenskioldi, $E$. $n$. pallida and singular $D$. octaedra were found. Also, the low-grass birch forest (VerhTula) is the only habitat studied where the large-sized E. n. nordenskioldi was not found, population density of the small-sized form being relatively high (Table 2 ).

On the resulting dendrogram of the ratio of living forms (Fig. 3), all small foliage forests are divided into two large groups:

1) in the forest in the vicinity of Morozovo settlement, upper-soil-layer endogeic earthworms (O. lacteum) are the predominant living form $(88 \%$ of the population);
2) the second group includes the rest of the forests, where the proportion of middlesoil-layer endogeic earthworms is about half of the total population. There are differences within this group: the three forests demonstrate a significant proportion of epigeic and epi-endogeic earthworms (epiendogeic earthworms in the vicinity of Kol'covo settlement and Verh-Tula village, epigeic earthworms in the vicinity of Shelkovichiha station), and in the forest in the vicinity of Bykovo village $33 \%$ of the population is comprised of upper-soil-layer endogeic earthworms. It should also be noted that epi-endogeic earthworms in the forests in the vicinity of Kol'covo settlement and VerhTula village are represented only by $E$. $n$. nordenskioldi, and the middle-soil-layer endogeic earthworms - by E. $n$. pallida. In the forests in the vicinity of Bykovo village and Shelkovichiha station, both subspecies are also found, but these living forms are predominantly represented by L. rubellus and A. c. caliginosa, respectively (Table 2).

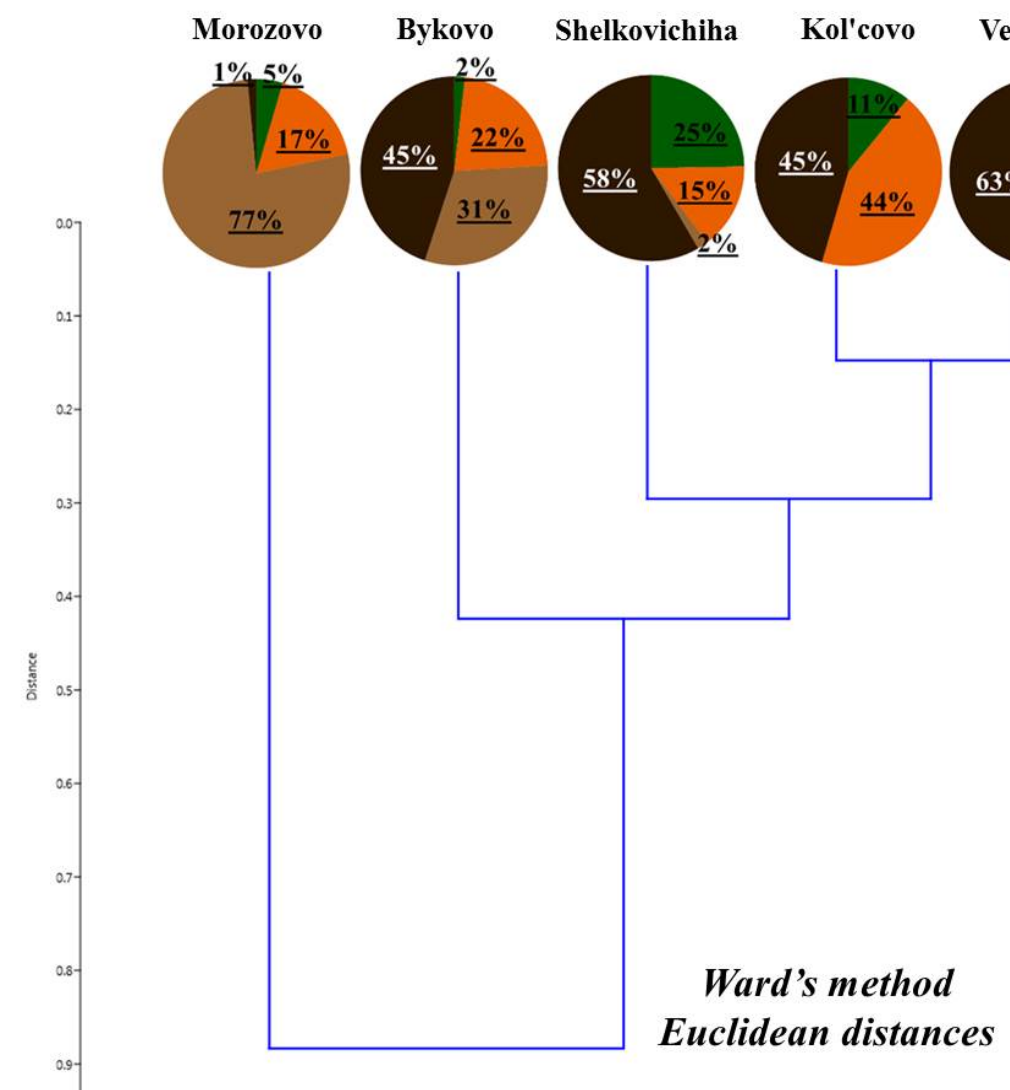

Figure 3. Ratio of living forms of earthworms in small foliage forests Note: here and elsewhere the legend is the same as for Fig. 2 
Table 2. Earthworm (Lumbricidae) population in small foliage forests $(X \pm S E)$

\begin{tabular}{|c|c|c|c|c|c|}
\hline $\begin{array}{l}\text { Type of } \\
\text { biotope }\end{array}$ & $\begin{array}{l}\text { Place of } \\
\text { sampling }\end{array}$ & Living forms & Species & $\begin{array}{c}\text { Population } \\
\text { density, } \\
\text { individuals/m } \\
\underset{2}{ }\end{array}$ & $\begin{array}{l}\text { Proportion of } \\
\text { the living } \\
\text { form, } \%\end{array}$ \\
\hline \multirow{16}{*}{ 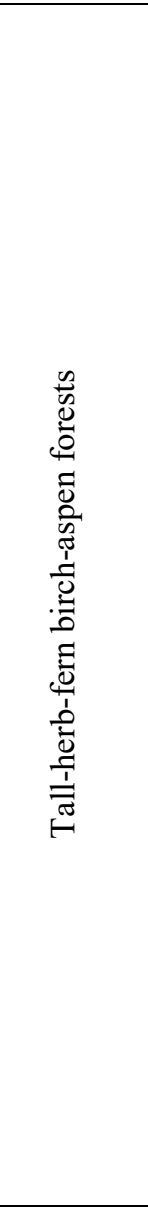 } & \multirow{7}{*}{$\begin{array}{c}\text { Vicinity of } \\
\text { Bykovo village }\end{array}$} & Epigeic & D. octaedra & $5 \pm 2$ & 2 \\
\hline & & \multirow{3}{*}{ Epi-endogeic } & L. rubellus & $39 \pm 14$ & \multirow{3}{*}{22} \\
\hline & & & $\begin{array}{c}\text { E. n. nordenskioldi } \\
\text { (small-sized) }\end{array}$ & $8 \pm 3$ & \\
\hline & & & $\begin{array}{l}\text { E. n. nordenskioldi } \\
\text { (large-sized) }\end{array}$ & $1 \pm 1$ & \\
\hline & & $\begin{array}{c}\text { Endogeic } \\
\text { (upper-soil-layer) }\end{array}$ & $\begin{array}{c}\text { O. lacteum } \\
\text { (small-sized) }\end{array}$ & $67 \pm 21$ & 31 \\
\hline & & \multirow{2}{*}{$\begin{array}{c}\text { Endogeic } \\
\text { (middle-soil-layer) }\end{array}$} & A. c. caliginosa & $95 \pm 34$ & \multirow{2}{*}{45} \\
\hline & & & E.n.pallida & $2 \pm 2$ & \\
\hline & \multirow{5}{*}{$\begin{array}{l}\text { Vicinity of } \\
\text { Morozovo } \\
\text { settlement }\end{array}$} & Epigeic & D. octaedra & $12 \pm 3$ & 5 \\
\hline & & \multirow{2}{*}{ Epi-endogeic } & $\begin{array}{c}\text { E. n. nordenskioldi } \\
\text { (small-sized) }\end{array}$ & $39 \pm 8$ & \multirow{2}{*}{17} \\
\hline & & & $\begin{array}{c}\text { E. n. nordenskioldi } \\
\text { (large-sized) }\end{array}$ & $6 \pm 2$ & \\
\hline & & $\begin{array}{c}\text { Endogeic } \\
\text { (upper-soil-layer) }\end{array}$ & $\begin{array}{l}\text { O. lacteum } \\
\text { (small-sized) }\end{array}$ & $202 \pm 29$ & 77 \\
\hline & & $\begin{array}{c}\text { Endogeic } \\
\text { (middle-soil-layer) }\end{array}$ & A. c. caliginosa & $4 \pm 2$ & 1 \\
\hline & \multirow{4}{*}{$\begin{array}{l}\text { Vicinity of } \\
\text { Kol'covo } \\
\text { settlement }\end{array}$} & Epigeic & D. octaedra & $6 \pm 3$ & 11 \\
\hline & & \multirow{2}{*}{ Epi-endogeic } & $\begin{array}{c}\text { E. n. nordenskioldi } \\
\text { (small-sized) }\end{array}$ & $23 \pm 6$ & \multirow{2}{*}{44} \\
\hline & & & $\begin{array}{c}\text { E. n. nordenskioldi } \\
\text { (large-sized) }\end{array}$ & $1 \pm 1$ & \\
\hline & & $\begin{array}{c}\text { Endogeic } \\
\text { (middle-soil-layer) }\end{array}$ & E.n.pallida & $25 \pm 6$ & 45 \\
\hline \multirow{8}{*}{ 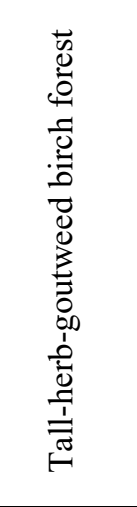 } & \multirow{8}{*}{$\begin{array}{c}\text { Vicinity of } \\
\text { Shelkovichiha } \\
\text { station }\end{array}$} & \multirow{2}{*}{ Epigeic } & D. octaedra & $64 \pm 16$ & \multirow{2}{*}{25} \\
\hline & & & D. r. tenuis & $3 \pm 2$ & \\
\hline & & \multirow{3}{*}{ Epi-endogeic } & L. rubellus & $27 \pm 12$ & \multirow{3}{*}{15} \\
\hline & & & $\begin{array}{c}\text { E. n. nordenskioldi } \\
\text { (small-sized) }\end{array}$ & $8 \pm 4$ & \\
\hline & & & $\begin{array}{c}\text { E. n. nordenskioldi } \\
\text { (large-sized) }\end{array}$ & $5 \pm 2$ & \\
\hline & & $\begin{array}{c}\text { Endogeic } \\
\text { (upper-soil-layer) }\end{array}$ & $\begin{array}{c}\text { O. lacteum } \\
\text { (small-sized) }\end{array}$ & $5 \pm 4$ & 2 \\
\hline & & \multirow{2}{*}{$\begin{array}{c}\text { Endogeic } \\
\text { (middle-soil-layer) }\end{array}$} & A. c. caliginosa & $146 \pm 48$ & \multirow{2}{*}{58} \\
\hline & & & E.n.pallida & $10 \pm 8$ & \\
\hline \multirow{3}{*}{ 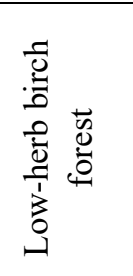 } & \multirow{3}{*}{$\begin{array}{l}\text { Vicinity of } \\
\text { Verh-Tula } \\
\text { village }\end{array}$} & Epigeic & D. octaedra & $1 \pm 1$ & 1 \\
\hline & & Epi-endogeic & $\begin{array}{c}\text { E. n. nordenskioldi } \\
\text { (small-sized) }\end{array}$ & $26 \pm 5$ & 36 \\
\hline & & $\begin{array}{c}\text { Endogeic } \\
\text { (middle-soil-layer) }\end{array}$ & E. n. pallida & $45 \pm 13$ & 63 \\
\hline
\end{tabular}




\section{Earthworm population in deadwood}

Deadwood suitable for earthworm sampling (Geraskina, 2016b, 2016c) was found only in five habitats: in three pine forests (Zael'covskij, Chemskoj, and in the vicinity of Baryshevo village) and in two small foliage forests (tall-herb-fern birchaspen forests in the vicinity of Bykovo village and of Kol'covo settlement). The studied deadwood was represented by single fallen trunks of Pinus sylvestris and Betula pendula of different sizes, stage 2-3 of decomposition.
Almost the entire population of deadwood was made up of epigeic and epi-endogeic earthworms, with rare occasional endogeic earthworms found in the trunks of decomposition stage 3 (Table 3, Table 4). It is particularly remarkable that in the pine forest in the vicinity of Baryshevo village and birchaspen forest in the vicinity of Kol'covo settlement, where the population density of earthworms in the soil was low, deadwood showed high population density and species composition diversity.

Table 3. Population of earthworms (Lumbricidae) in the deadwood of pine forests

\begin{tabular}{|c|c|c|c|c|c|}
\hline $\begin{array}{c}\text { Place of } \\
\text { sampling }\end{array}$ & $\begin{array}{c}\text { Stage of } \\
\text { decomposition, } \\
\text { type of wood }\end{array}$ & Living forms & Species & $\begin{array}{c}\text { Population } \\
\text { density, } \\
\text { individuals } / \mathbf{m}^{3}\end{array}$ & $\begin{array}{l}\text { Proportion } \\
\text { of the } \\
\text { living } \\
\text { form, } \% \\
\end{array}$ \\
\hline \multicolumn{6}{|c|}{ Tall-herb-fern pine forests } \\
\hline \multirow{4}{*}{$\begin{array}{l}\text { Zael'covskij } \\
\text { pine forest }\end{array}$} & \multirow{4}{*}{2 , pine tree } & \multirow{2}{*}{ Epigeic } & D. octaedra & 101 & \multirow{2}{*}{88} \\
\hline & & & D. r.tenuis & 8 & \\
\hline & & \multirow{2}{*}{ Epi-endogeic } & L. rubellus & 14 & \multirow{2}{*}{12} \\
\hline & & & E. n. nordenskioldi (small-sized) & 1 & \\
\hline \multirow{4}{*}{$\begin{array}{l}\text { Chemskoj pine } \\
\text { forest }\end{array}$} & \multirow{4}{*}{ 2, birch } & \multirow{2}{*}{ Epigeic } & D. octaedra & 64 & \multirow{2}{*}{54} \\
\hline & & & D. r. tenuis & 48 & \\
\hline & & Epi-endogeic & E. n. nordenskioldi (small-sized) & 84 & 40 \\
\hline & & $\begin{array}{c}\text { Endogeic } \\
\text { (middle-soil-layer) }\end{array}$ & E.n.pallida & 12 & 6 \\
\hline \multirow{11}{*}{$\begin{array}{l}\text { Pine forest in } \\
\text { the vicinity of } \\
\text { Baryshevo } \\
\text { village }\end{array}$} & \multirow{3}{*}{2 , pine tree } & \multirow{2}{*}{ Epigeic } & D. octaedra & 192 & \multirow{2}{*}{99} \\
\hline & & & D. r. tenuis & 169 & \\
\hline & & Epi-endogeic & E. n. nordenskioldi (small-sized) & 4 & 1 \\
\hline & \multirow{5}{*}{3 , pine } & \multirow{2}{*}{ Epigeic } & D. octaedra & 12 & \multirow{2}{*}{44} \\
\hline & & & D.r.tenuis & 13 & \\
\hline & & Epi-endogeic & E. n. nordenskioldi (small-sized) & 14 & 25 \\
\hline & & $\begin{array}{c}\text { Endogeic } \\
\text { (upper-soil-layer) }\end{array}$ & O. lacteum (small-sized) & 17 & 29 \\
\hline & & $\begin{array}{c}\text { Endogeic } \\
\text { (middle-soil-layer) }\end{array}$ & E.n. pallida & 1 & 2 \\
\hline & \multirow{3}{*}{ 3, birch } & \multirow{2}{*}{ Epigeic } & D. octaedra & 164 & \multirow{2}{*}{88} \\
\hline & & & D.r.tenuis & 120 & \\
\hline & & Epi-endogeic & E.n. nordenskioldi (small-sized) & 40 & 12 \\
\hline
\end{tabular}

The species composition of earthworms in the deadwood of the Chemskoj and Zael'covskij pine forests and in the birchaspen forest in the vicinity of Bykovo village is similar to that in the soil of these habitats, with the exception of the $D$. $r$. tenuis subspecies (Eisen, 1874), which is common mainly in the deadwood (Geraskina, 2016a; Ermolov, 2018a). Also, deadwood of the forest in the vicinity Bykovo village was the only habitat where the epi-endogeic Eisenia fetida (Savigny, 1896) was found, which is synanthropic in Novosibirsk area (Ermolov, 2018, 2018a, 2019). 
Table 4. Population of earthworms (Lumbricidae) in the deadwood of small foliage forests

\begin{tabular}{|c|c|c|c|c|c|}
\hline $\begin{array}{c}\text { Place of } \\
\text { sampling }\end{array}$ & $\begin{array}{c}\text { Stage of } \\
\text { decomposition, } \\
\text { type of wood }\end{array}$ & Living forms & Species & $\begin{array}{c}\text { Population } \\
\text { density, } \\
\text { individuals/m } / \mathbf{m}^{3}\end{array}$ & $\begin{array}{c}\text { Proportion } \\
\text { of the } \\
\text { living } \\
\text { form, } \% \\
\end{array}$ \\
\hline \multicolumn{6}{|c|}{ Tall-herb-fern birch-aspen forests } \\
\hline \multirow{12}{*}{$\begin{array}{c}\text { Vicinity of } \\
\text { Bykovo village }\end{array}$} & \multirow{4}{*}{ 2, birch No. 1} & \multirow{2}{*}{ Epigeic } & D. octaedra & 500 & \multirow{2}{*}{81} \\
\hline & & & D.r.tenuis & 600 & \\
\hline & & \multirow{2}{*}{ Epi-endogeic } & L. rubellus & 20 & \multirow{2}{*}{19} \\
\hline & & & E. n. nordenskioldi (small-sized) & 240 & \\
\hline & \multirow{3}{*}{ 2, birch No. 2} & Epigeic & D. r. tenuis & 25 & 5 \\
\hline & & \multirow{2}{*}{ Epi-endogeic } & L. rubellus & 100 & \multirow{2}{*}{95} \\
\hline & & & E. n. nordenskioldi (small-sized) & 350 & \\
\hline & \multirow{5}{*}{ 3, birch } & Epigeic & D. r. tenuis & 7 & 22 \\
\hline & & \multirow{3}{*}{ Epi-endogeic } & L. rubellus & 6 & \multirow{3}{*}{77} \\
\hline & & & E. n. nordenskioldi (small-sized) & 16 & \\
\hline & & & E. fetida & 2 & \\
\hline & & $\begin{array}{c}\text { Endogeic } \\
\text { (middle-soil-layer) }\end{array}$ & A. c. caliginosa & 1 & 1 \\
\hline \multirow{4}{*}{$\begin{array}{l}\text { Vicinity of } \\
\text { Kol'covo } \\
\text { settlement }\end{array}$} & \multirow{4}{*}{ 2, birch } & \multirow{3}{*}{ Epigeic } & D. octaedra & 4 & \multirow{3}{*}{30} \\
\hline & & & D. r. tenuis & 50 & \\
\hline & & & D. r. subrubicundus & 62 & \\
\hline & & Epi-endogeic & E. n. nordenskioldi (small-sized) & 273 & 70 \\
\hline
\end{tabular}

Deadwood was subjected to classification according to the ratio of living forms of earthworms (Fig. 4). Deadwood was divided into three groups:

1) deadwood with a predominance of epigeic earthworms;

2) deadwood with a predominance of epiendogeic forms;

3) deadwood with the presence of endogeic earthworms.

Despite the similar ratio of living forms, deadwood within one group differs in terms of predominant types of earthworms belonging to the same living form. For example, in the first group, the deadwood of the Zael'covskij pine forest has the same ratio of living forms as that in the vicinity of Baryshevo village (Fig. 4). However, in the Zael'covskij pine forest, almost all epigeic earthworms belong to D. octaedra, epiendogeic earthworms - to L. rubellus, and in the pine forest in the vicinity of Baryshevo village (as, indeed, in the other deadwood in this group) the epigeic earthworms are represented by $D$. octaedra and $D$. r. tenuis, with the population density ratio of almost $1: 1$ (Table 3, Table 4), and E. n. nordenskioldi (small-sized) represent the majority of epiendogeic earthworms. In the group with the predominance of epi-endogeic earthworms, deadwood in the vicinity of Bykovo village was inhabited by three different representatives of this living form ( $L$. rubellus, E. fetida, E. n. nordenskioldi (smallsized)), whereas in the vicinity of Kol'covo it was represented by E. n. nordenskioldi only (small-sized); also, only in the deadwood in the vicinity of Kol'covo the epigeic subspecies D. r. subrubicundus was common. In highly decomposed pine trunk in the pine forest in the vicinity of Baryshevo, endogeic earthworms $O$. lacteum that were also sporadically found in the soil of that forest, were found; in the deadwood of the Chemskoj pine forest the proportion of middle-soil-layer endogeic E. n. pallida was relatively high; there was no marked predominance among the other forms in the deadwood of this group. 


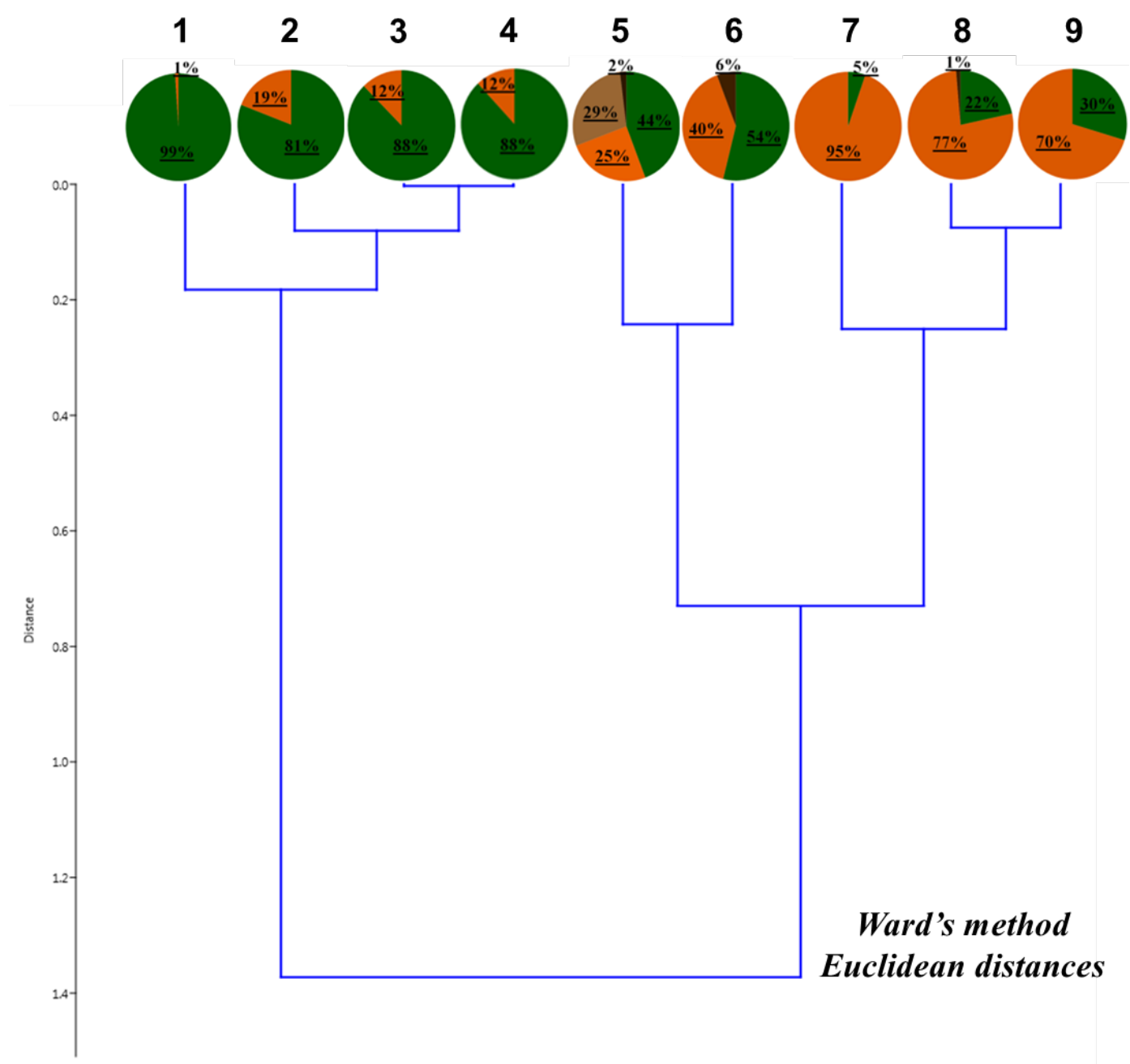

Figure 4. The proportion of living forms of earthworms in the deadwood Note: 1 - Baryshevo (pine, st. 2); 2 - Bykovo (birch No. 1, st. 2); 3 -Zael'covskij pine forest (pine, st. 2); 4 - Baryshevo (birch, st. 3); 5 - Baryshevo (pine, st. 3); 6 - Chemskoj pine forest (birch, st. 2); 7 - Bykovo (birch No. 2, st. 2); 8 - Bykovo (birch, st. 3); 9 - Kol'covo (birch, st. 2)

The relationship between soil properties and the species composition of earthworms. The measured physical and chemical soil properties in the studied pine forests and small foliage forests are shown below (Tables 5 and 6).

Table 5. Physical and chemical properties of pine forest soils $(X \pm S E)$

\begin{tabular}{|c|c|c|c|c|}
\hline Place of sampling & $\begin{array}{c}\text { Litter thickness, } \\
\mathbf{c m}\end{array}$ & $\begin{array}{c}\text { Humus horizon } \\
\text { thickness, cm }\end{array}$ & $\begin{array}{c}\text { Moisture content in } \\
\text { the soil, \% }\end{array}$ & $\begin{array}{c}\text { Soil acidity, pH of } \\
\text { the water }\end{array}$ \\
\hline Chemskoj pine forest & $3.3 \pm 0.1$ & $6.8 \pm 0.4$ & $20.06 \pm 1.88$ & $5.81 \pm 0.08$ \\
\hline Zael'covskij pine forest & $2.3 \pm 0.2$ & $10.4 \pm 0.5$ & $30.44 \pm 3.21$ & $5.72 \pm 0.06$ \\
\hline $\begin{array}{c}\text { Kudrjashovskij pine } \\
\text { forest }\end{array}$ & $2.4 \pm 0.1$ & $9.9 \pm 0.7$ & $25.25 \pm 2.22$ & $5.38 \pm 0.04$ \\
\hline $\begin{array}{c}\text { Pine forest in the vicinity } \\
\text { of Sosnovka settlement }\end{array}$ & $3.5 \pm 0.3$ & $5.0 \pm 0.4$ & $34.81 \pm 3.65$ & $5.36 \pm 0.05$ \\
\hline $\begin{array}{c}\text { Pine forest in the vicinity } \\
\text { of Baryshevo village }\end{array}$ & $3.6 \pm 0.2$ & $10.5 \pm 0.7$ & $22.50 \pm 2.87$ & $5.96 \pm 0.07$ \\
\hline
\end{tabular}


Table 6. Physical and chemical properties of small foliage forest soils $(X \pm S E)$

\begin{tabular}{|c|c|c|c|c|}
\hline Name of the biotope & $\begin{array}{c}\text { Litter thickness, } \\
\mathbf{~ c m}\end{array}$ & $\begin{array}{c}\text { Humus horizon } \\
\text { thickness, cm }\end{array}$ & $\begin{array}{c}\text { Moisture content in } \\
\text { the soil, \% }\end{array}$ & $\begin{array}{c}\text { Soil acidity, pH of } \\
\text { the water }\end{array}$ \\
\hline $\begin{array}{c}\text { Vicinity of Bykovo } \\
\text { village }\end{array}$ & $1.6 \pm 0.2$ & $9.9 \pm 1.1$ & $28.00 \pm 2.24$ & $5.68 \pm 0.09$ \\
\hline $\begin{array}{c}\text { Vicinity of Morozovo } \\
\text { settlement }\end{array}$ & $2.0 \pm 0.2$ & $19.9 \pm 1.1$ & $21.50 \pm 0.86$ & $6.22 \pm 0.08$ \\
\hline $\begin{array}{c}\text { Vicinity of Kol'covo } \\
\text { settlement }\end{array}$ & $2.8 \pm 0.2$ & $10.3 \pm 0.6$ & $21.06 \pm 0.88$ & $6.23 \pm 0.06$ \\
\hline $\begin{array}{c}\text { Vicinity of } \\
\text { Shelkovichiha station }\end{array}$ & $2.2 \pm 0.1$ & $12.3 \pm 0.5$ & $39.19 \pm 1.63$ & $5.42 \pm 0.08$ \\
\hline $\begin{array}{c}\text { Vicinity of Verh-Tula } \\
\text { village }\end{array}$ & $3.4 \pm 0.2$ & $9.8 \pm 0.7$ & $17.56 \pm 0.75$ & $6.35 \pm 0.08$ \\
\hline
\end{tabular}

The diagram for pine forests shows that soil humidity is the most significant factor affecting the population density of epigeic and epi-endogeic earthworms (Fig. 5). Their population density shows a significant correlation with the indicators of soil humidity $\left(\mathrm{r}_{\mathrm{s}}=0.89 ; \mathrm{p}<0.05 ; \mathrm{n}=5\right)$. Earthworms of these groups live near the surface of the soil and are therefore more sensitive to drying out. In these habitats, moisture is retained mainly due to the litter, since sod-podzolic soils and sod-podzolic sandy soils typical of pine forests, retain very little moisture necessary for the normal life of earthworms. No correlations with other soil properties were found in this group.

No connection with soil characteristics other than humidity was found withing the group of endogeic earthworms. Positive connection was found between the population density of E. $n$. pallida and soil humidity $\left(\mathrm{r}_{\mathrm{s}}=0.90 ; \mathrm{p}<0.05, \mathrm{n}=4\right)$ and negative connection between the population density of A. c. caliginosa and soil humidity $\left(\mathrm{r}_{\mathrm{s}}=-0.90 ; \mathrm{p}\right.$ $<0.05$; n=4) (Fig. 6).

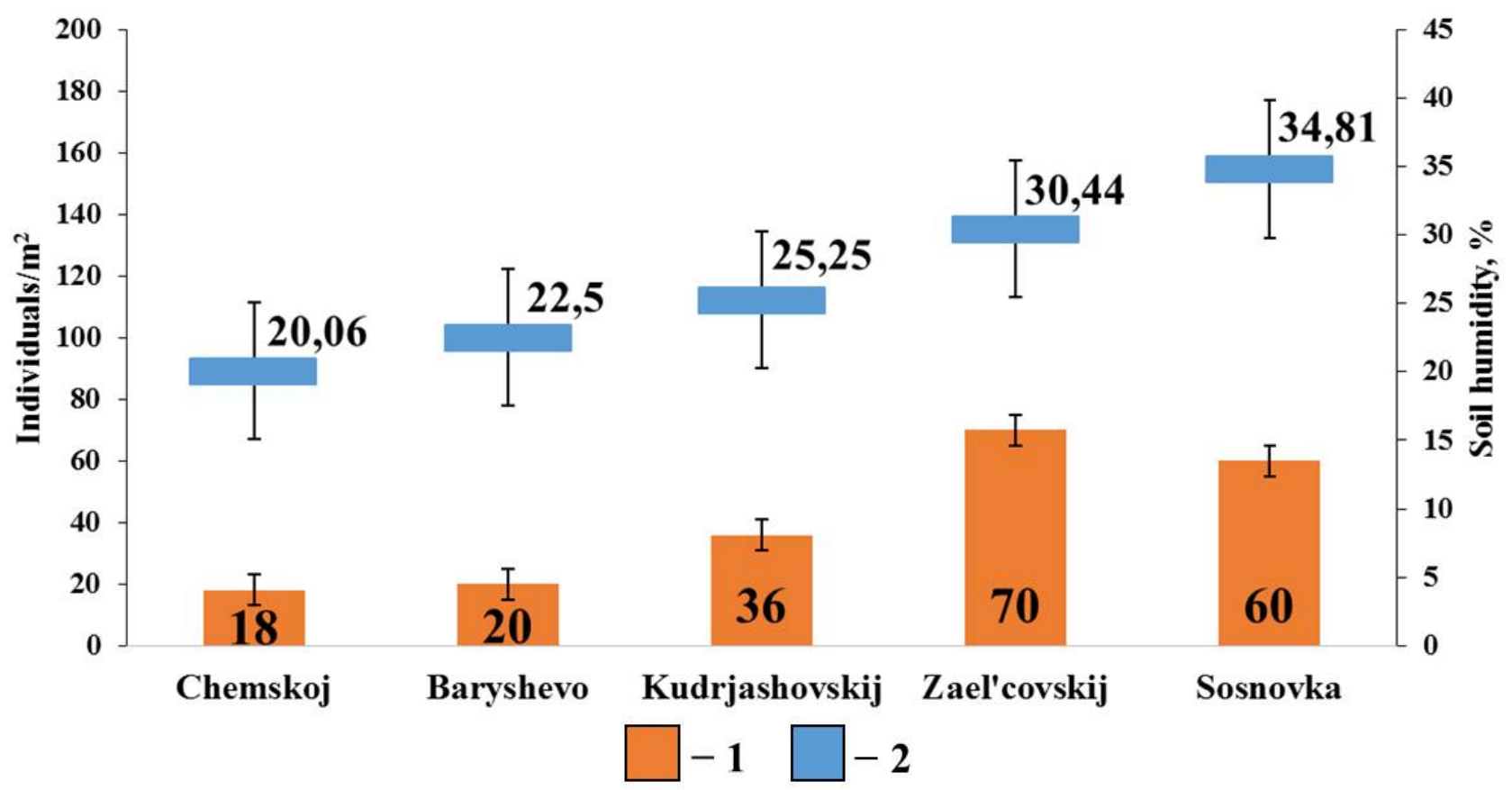

Figure 5. Correlation between the population density of epigeic and epi-endogeic earthworms and soil humidity in pine forests

Note. 1 - population density of epigeic and epi-endogeic earthworms; 2 - soil humidity 


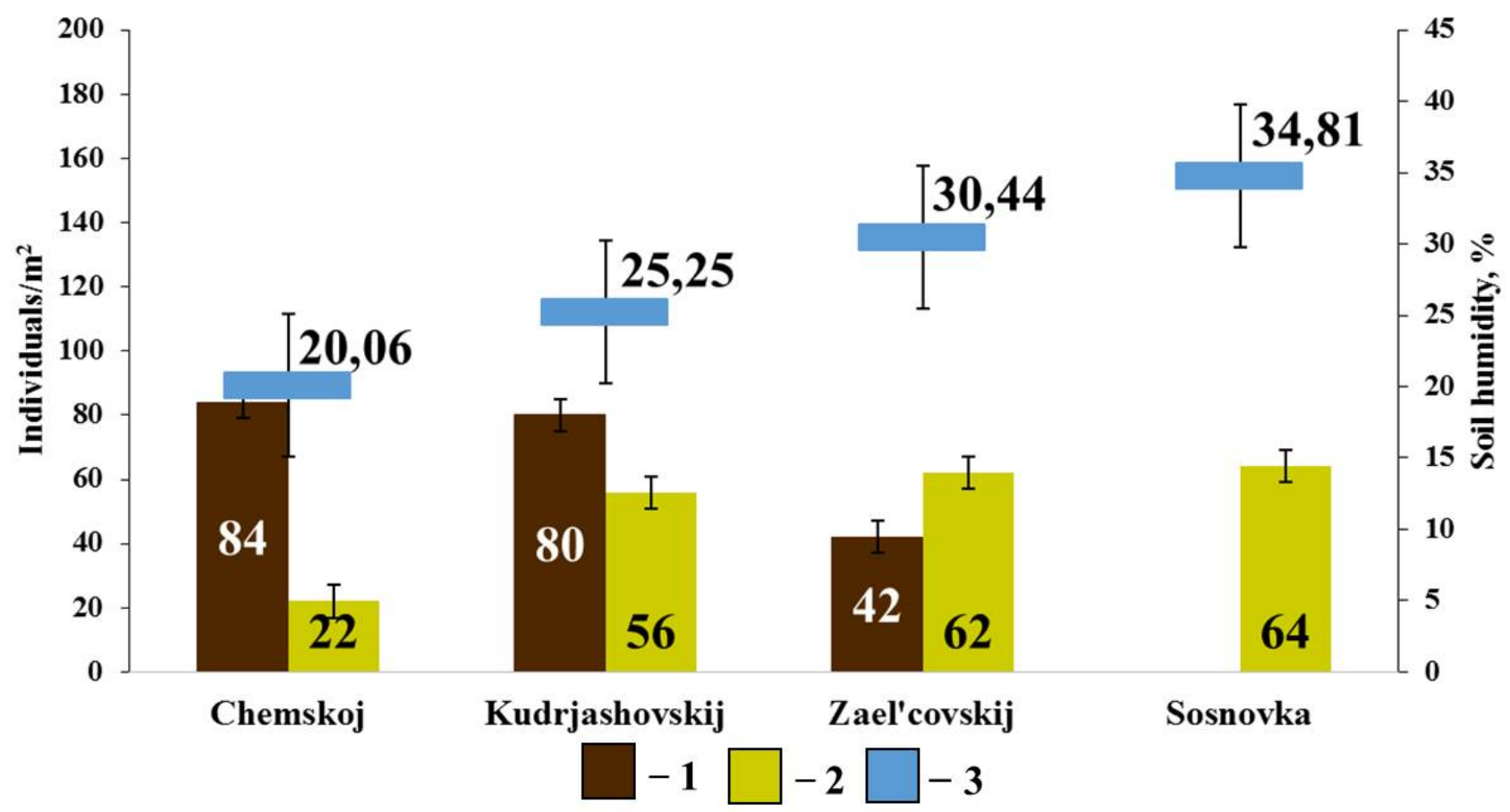

Figure 6. Correlation between the population density of endogeic earthworms and soil humidity in pine forests

Note. 1 - A. caliginosa caliginosa; 2 - E. nordenskioldi pallida; 3 - soil humidity

In small foliage forests with gray forest soils, positive correlations were found between the total density of epigeic and epiendogeic earthworms and soil humidity $\left(\mathrm{r}_{\mathrm{s}}=0.89 ; \quad \mathrm{p} \quad<0.05 ; \mathrm{n}=5\right) \quad$ (Fig. 7). No significant correlations were found with other soil characteristics.

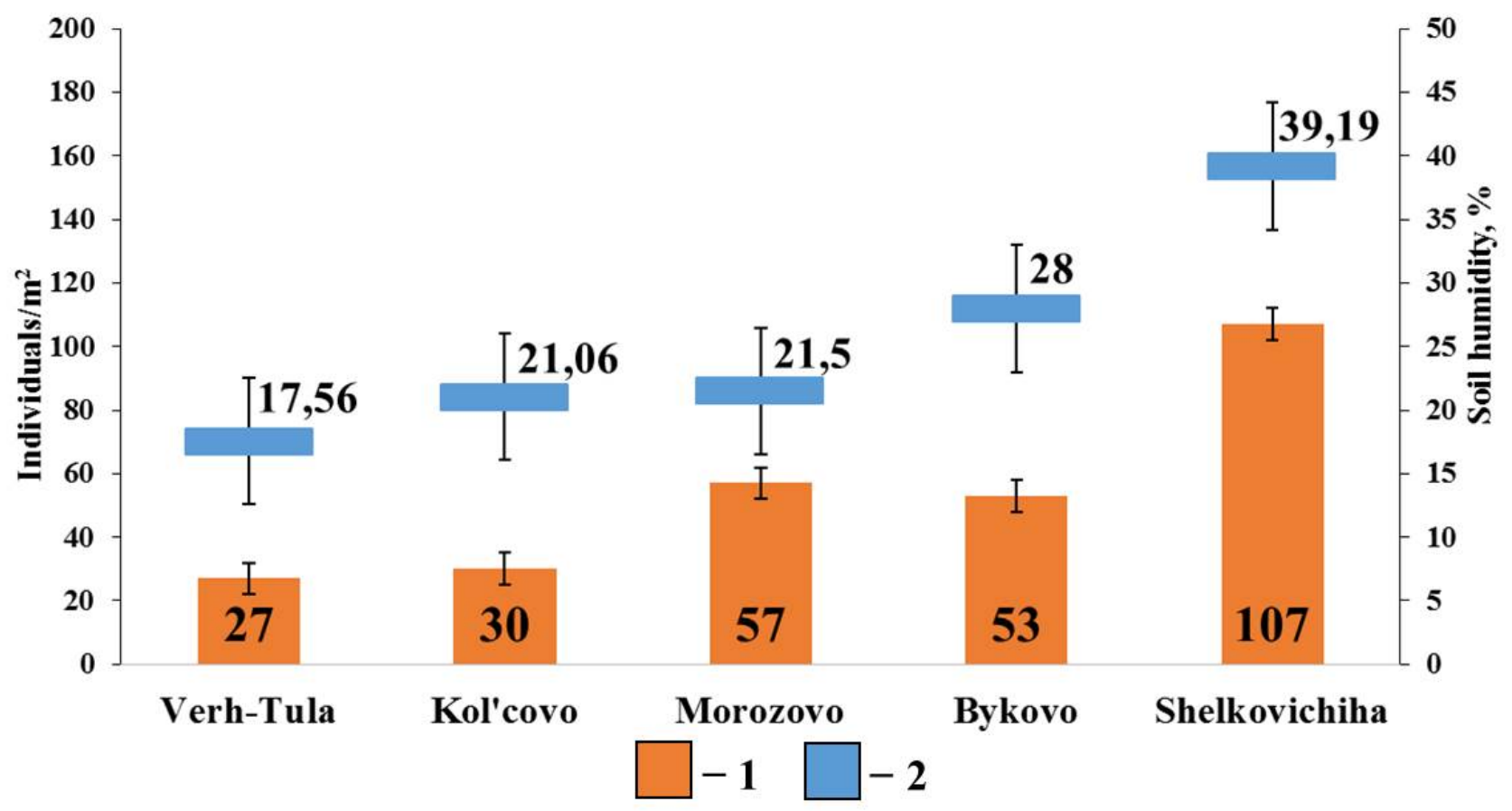

Figure 7. Correlation between the population density of epigeic and epi-endogeic earthworms and soil humidity in small foliage forests

Note. 1 - population density of epigeic and epi-endogeic earthworms; 2 - soil humidity 


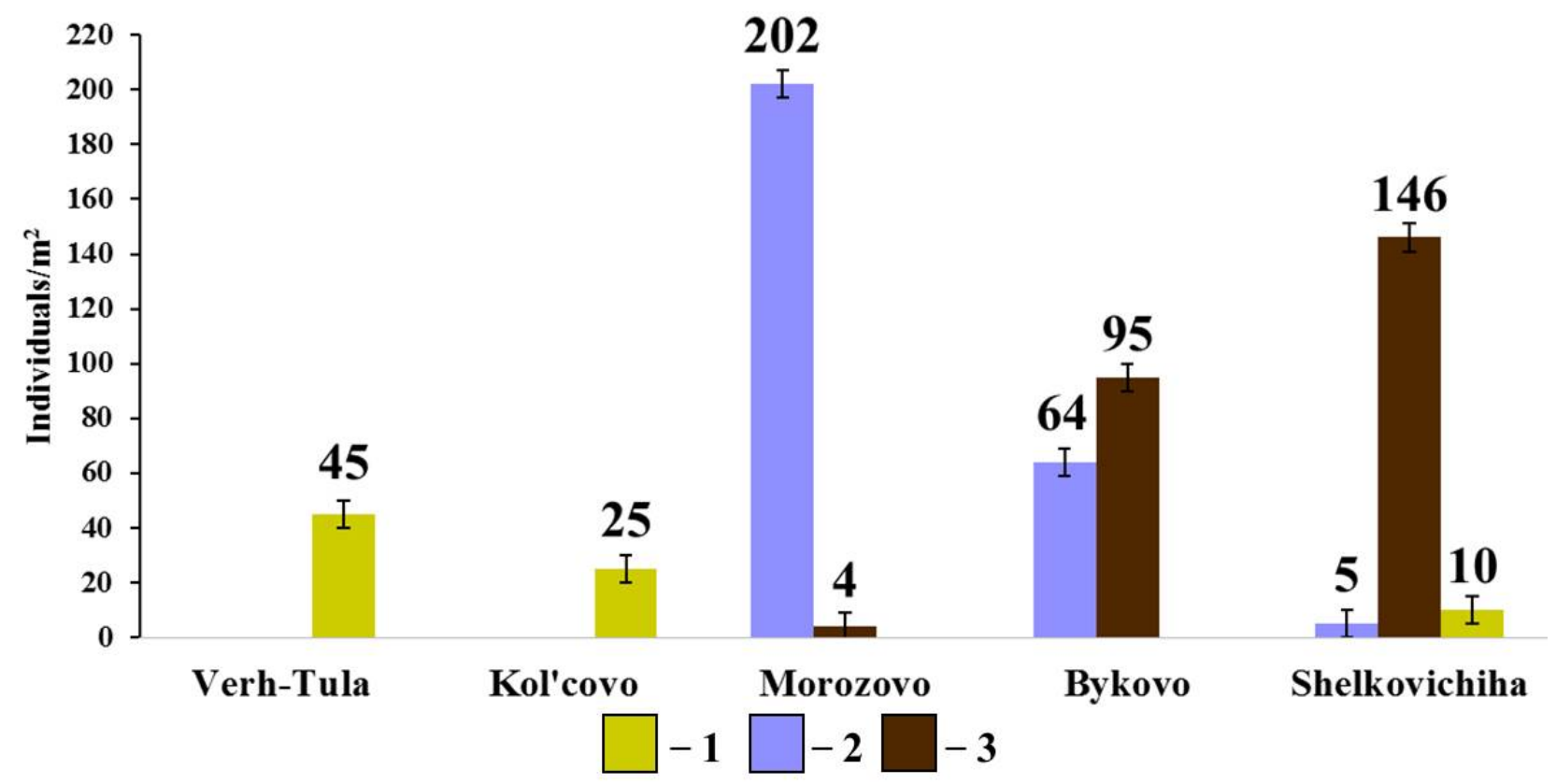

Figure 8. Diversity of species composition and population density of endogeic earthworms in small foliage forests

Note. 1 - E. nordenskioldi pallida; 2 - O. lacteum; 2 - A. caliginosa caliginosa

In the group of endogeic earthworms, no correlation between the total population density and the population density of individual species with soil properties was found. However, it should be noted that, unlike in the pine forests, the species composition and population density of this group of earthworms in small foliage forests vary greatly (Fig. 8). The forest in the vicinity of Morozovo settlement with a thick humus horizon $(19.9 \mathrm{~cm})$ and slightly acidic soil reaction $\left(\mathrm{pH}_{\text {water }}=6.22\right)$ is dominated by $O$. lacteum, whereas the forests in the vicinity of Bykovo and Shelkovichiha with acidic soil reaction $\left(\mathrm{pH}_{\text {water }}=5.68\right.$ and 5.42, respectively) and a less developed humus horizon $(12.3 \mathrm{~cm}$ and $9.9 \mathrm{~cm}$, respectively) are dominated by $A . c$. caliginosa. The density of E. $n$. pallida population in small foliage forests is noticeably lower than in pine forests, which cannot be explained by the measured soil characteristics.

Morphometric analysis of $E$. $n$. nordenskioldi. This study demonstrated that individuals of $E$. $n$. nordenskiold $i$ subspecies of the epi-endogeic earthworms vary markedly in their size: it is visually possible to distinguish between the small-sized and large-sized forms (Fig. 9). The results of morphometric analysis of samples of different-sized earthworms are shown below (Table 7).

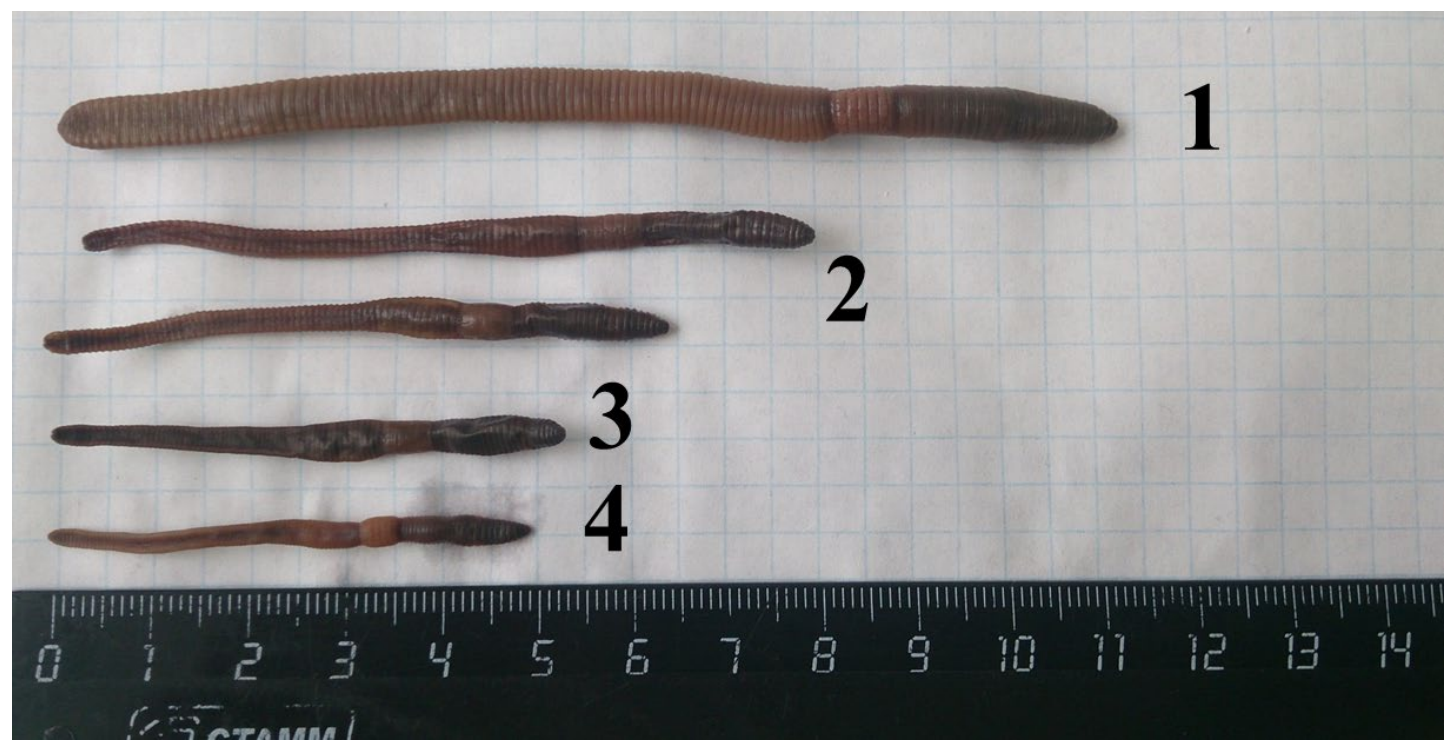

Figure 9. Polymorphism of E. n. nordenskioldi

Note. 1 - large-sized, soil; 2 - Kol'covo, deadwood; 3 - Bykovo, deadwood; 4 - Verh-Tula, soil. 
Table 7. Morphometric analysis of E. n. nordenskioldi individuals $(X \pm S E)$

\begin{tabular}{|c|c|c|c|c|c|c|c|c|c|}
\hline $\begin{array}{c}\text { Sample } \\
\text { No. }\end{array}$ & $\begin{array}{c}\text { Place of } \\
\text { sampling }\end{array}$ & $\begin{array}{c}\text { Number of } \\
\text { individuals }\end{array}$ & $\begin{array}{c}\text { Number of } \\
\text { segments }\end{array}$ & $\begin{array}{c}\text { Body } \\
\text { length, mm }\end{array}$ & $\begin{array}{c}\text { Body width, } \\
\text { mm }\end{array}$ & $\begin{array}{c}\text { Clitellum } \\
\text { length, } \\
\text { mm }\end{array}$ & $\begin{array}{c}\text { Clitellum } \\
\text { width, } \\
\text { mm }\end{array}$ & Weight, g \\
\hline 1 & Verh-Tula, soil & 11 & $114 \pm 5$ & $48.7 \pm 1.5$ & $2.7 \pm 0.1$ & $4.2 \pm 0.2$ & $2.9 \pm 0.1$ & $0.2 \pm 0.01$ \\
\hline 2 & $\begin{array}{c}\text { Bykovo, } \\
\text { deadwood }\end{array}$ & 20 & $106 \pm 1$ & $53.5 \pm 1.0$ & $3.1 \pm 0.1$ & $4.4 \pm 0.1$ & $3.2 \pm 0.1$ & $0.25 \pm 0.01$ \\
\hline 3 & $\begin{array}{c}\text { Kol'covo, } \\
\text { deadwood }\end{array}$ & 17 & $102 \pm 2$ & $61.0 \pm 1.7$ & $3.2 \pm 0.1$ & $3.7 \pm 0.1$ & $3.2 \pm 0.1$ & $0.3 \pm 0.01$ \\
\hline \multicolumn{7}{|c|}{ Large-sized } \\
\hline 4 & Pine forests & 9 & $133 \pm 7$ & $114.2 \pm 5.6$ & $6.0 \pm 0.3$ & $6.7 \pm 0.4$ & $4.9 \pm 0.2$ & $1.8 \pm 0.2$ \\
\hline 5 & $\begin{array}{c}\text { Small foliage } \\
\text { forests }\end{array}$ & 7 & $126 \pm 5$ & $104.9 \pm 3.9$ & $5.2 \pm 0.1$ & $6.1 \pm 0.2$ & $5.3 \pm 0.2$ & $1.5 \pm 0.2$ \\
\hline
\end{tabular}

The largest number of features (5-6), for which statistically significant differences were revealed, was found when comparing samples of large-sized and small-sized forms of $E$. $n$. nordenskioldi. When comparing samples of small-sized forms with each other, we revealed no more than 3 features that show statistically significant differences. Samples of large-sized forms for pine forests and small foliage forests do not significantly differ (Table 8). Therefore, in this paper, we show the population density indicators for both large-sized and small-sized forms of $E$. $n$. nordenskioldi separately.

Table 8. List of statistically significant differences between samples

(Mann-Whitney U-test, $\mathrm{p}<0.01$ )

\begin{tabular}{|c|c|c|c|c|}
\hline Sample No. & $\mathbf{2}$ & $\mathbf{3}$ & $\mathbf{4}$ & $\mathbf{5}$ \\
\hline $\mathbf{1}$ & SN, BW, W & SN, BL, BW, W & BL, BW, CL, CW, W & BL, BW, CL, CW, W \\
\hline $\mathbf{2}$ & - & BL, CL, W & SN, BL, BW, CL, CW, W & SN, BL, BW, CL, CW, W \\
\hline $\mathbf{3}$ & & - & SN, BL, BW, CL, CW, W & SN, BL, BW, CL, CW, W \\
\hline
\end{tabular}

Note. For legend, see Materials and Methods

\section{DISCUSSION}

When studying the polymorphism of $E$. $n$. nordenskioldi, it should be noted that the small-sized form mainly inhabits deadwood and is less common in the soil, while the large-sized form lives only in the soil, often at a depth of more than 15-20 cm, although it feeds on the surface. There is an assumption that large-sized individuals belong to the anecic worms. A similar point of view has already been proposed during the research of the forests of the Western Sayan Mountains and the soils of Yakutia (Perel', 1994; Boeskorov, 2004), where large-sized and small-sized forms of this subspecies were also found, and the large form was characterised as anecic. It should also be mentioned that in the earthworm samples collected by Ju. B. Byzova in birch forests in the vicinity of
Novosibirsk, large-sized individuals of $E$. $n$. nordenskioldi of a certain size and weight were considered anecic (Byzova, 2007).

These statements can be confirmed by the following observation: when comparing the large-sized form of E. n. nordenskioldi with the typical representative of anecic worms $L$. terrestris, one can note the similarity in their external morphology (Fig. 10). In particular, the large-sized form has a pronounced flattening of the body and a weakening of pigmentation from the head end towards the tail, whereas in small-sized worms there is no pronounced flattening of the body, and the pigmentation of the body is very even. However, it is not yet possible to univocally assert that the large-sized form of $E$. $n$. nordenskioldi found in Novosibirsk area can 
be categorised as anecic; this would require detailed studies of the internal morphology, as well as looking for long vertical passages in the soil, typical of anecic earthworms.

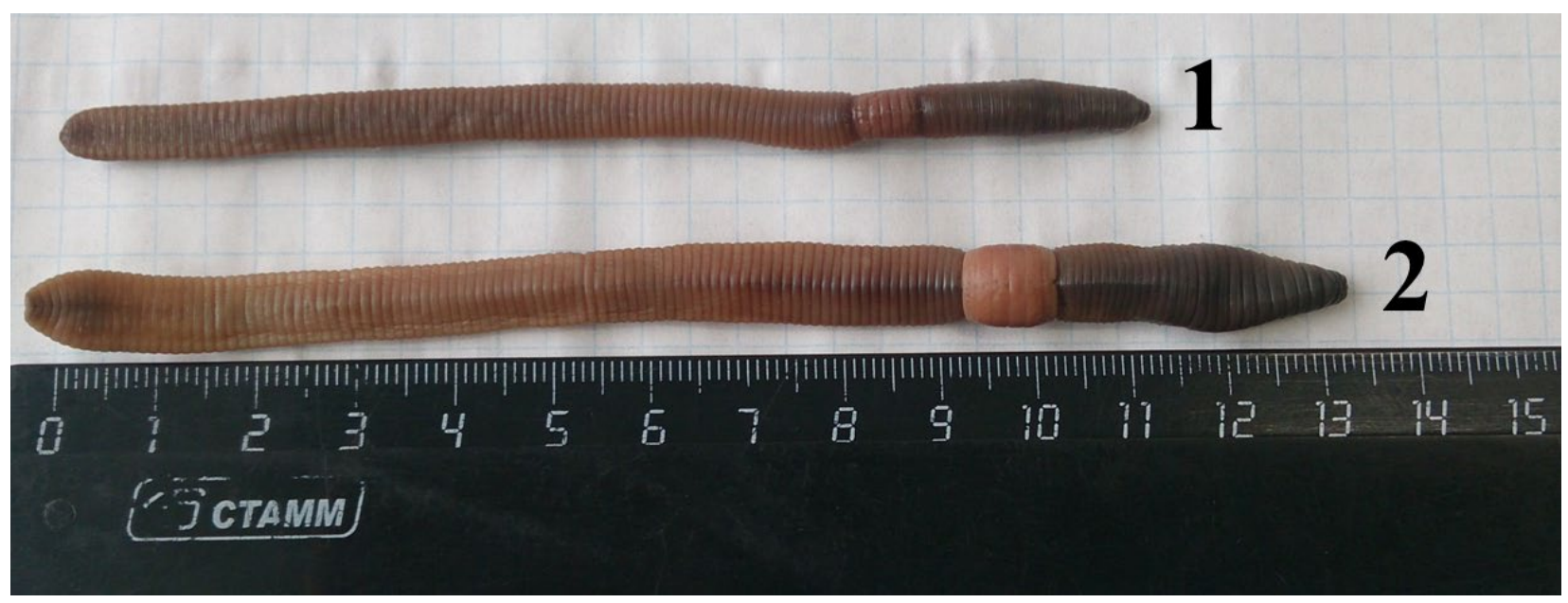

Figure 10. Similarity of the external appearance between the large-sized forms of E. n. nordenskioldi (1) and L. terrestris (2)

A similar study was conducted for $O$. lacteum. Novosibirsk area is habitat to largesized and small-sized forms of this species that have significant differences not only in morphological features, but also at the molecular and genetic level (Shehovcov, Ermolov et al., 2020). The large-sized form of O. lacteum is mainly confined to floodplain biotopes, while in the forests, only the smallsized form is found.

The population of earthworms in pine forests and small foliage forests was generally similar in terms of species composition and the ratio of living forms, but the population density of worms in small foliage forests is much higher than in pine forests. Even in a dry low-grass birch forest (Verh-Tula), the population density was higher than in the most "poorly" populated pine forest (Baryshevo). However, the population of earthworms in tall-herb-fern pine forests is noticeably more diverse than in dark coniferous forests (Geras'kina, 2016b) and Southern taiga (Krylova et al., 2011), where there were usually no endogeic earthworms at all, while epigeic and epi-endogeic earthworms are represented by one species. Birch-aspen forests of the forest-steppe $\mathrm{Ob}$ region (Novosibirsk area) have a diverse species composition and high population density of earthworms, which nevertheless is still inferior to small foliage and broad foliage forests in the European part of Russia (Perel', 1958; Akkumuljacija..., 2018; Geraskina, 2016, 2016a). The main difference between the complexes of living forms of earthworms in Novosibirsk area and the above-mentioned regions is the absence of typical anecic forms (if we don't consider the large-sized form of E. n. nordenskioldi as one). Anecic earthworms are represented $L$. terrestris, which is extremely rare here; it inhabits anthropogenic territories and was not found in natural habitats (Ermolov, 2018a, 2019).

In the studied forests, population density of endogeic earthworms is much higher than that of epigeic and epi-endogeic earthworms. Most of the population of epigeic and epiendogeic earthworms is concentrated in the forest deadwood, earthworms even reproduce there, as evidenced by cocoons found (Geraskina, 2016c; Ermolov, 2018a). Deadwood effectively maintains the diversity of epigeic and epi-endogeic earthworms in forest ecosystems. In different habitats, the ratio of epigeic and epi-endogeic earthworms in deadwood may differ, but the species composition is almost always similar to that in the soil (Tables 1, 2, 3, and 4). Endogeic earthworms can also be found in deadwood. 
They mainly inhabit heavily decomposed trunks and are represented by juvenile individuals, which usually live close to the soil surface. Adult individuals are found in deadwood much less often and seem to use it as a temporary habitat; for example, to crawl there after leaving the soil during rain (Chekanovskaja, 1960; Geraskina, 2016c).

It should also be noted that among epigeic and epi-endogeic earthworms in the soil, the population density of cosmopolitans (D. $r$. tenuis, D. octaedra, L. rubellus) and the Asian subspecies ( $E$. n. nordenskioldi) is approximately the same in different habitats, and among the endogeic earthworms, cosmopolitans (O. lacteum, A. c. caliginosa) are much more common than the Asian subspecies E. n. pallida. Some species of epigeic and epi-endogeic earthworms are not confined to specific soil factors, and total density of their population directly depends on soil humidity, since these groups live near the very surface of the soil and are therefore more sensitive to drying out (Chekanovskaja, 1960; Perel', 1979; Geraskina, 2016a). At high humidity, worms of this ecological group are abundant even in acidic soil, especially in small foliage forests $\left(\mathrm{pH}_{\mathrm{water}}=5.42\right)$, where the litter is more nutritious than in pine forests (Holdsworth et al., 2008). Nevertheless, epigeic and epi-endogeic earthworms have less influence on soil $\mathrm{pH}$, and therefore the correlation between their population density and this factor requires more detailed studies. No direct correlations were found with the litter thickness, but in forests with L. rubellus (Zael'covskij pine forest, Bykovo), the litter thickness was noted to be the smallest, since this species processes litter more intensively than other epigeic and epi-endogeic earthworms (Golovanova et al., 2018). There was a correlation between the population density of individual species of endogeic earthworms and soil humidity in pine forests. The negative correlation of $A$. c. caliginosa population density with soil humidity is probably due to the fact that this subspecies is capable of summer diapause and therefore can better tolerate drought than other earthworm species (Perel', 1975, 1979). In wetter soils, however, the population density of other species, which may outnumber $A . \quad c$. caliginosa, increases. No significant correlations were observed in small foliage forests. At the same time, the studied small foliage forests differed greatly in the species composition of endogeic earthworms: in the birch-aspen forest in the vicinity of Morozovo settlement, O. lacteum prevailed, which can be explained by a thick humus horizon and weak soil acidity. This type is usually predominant in waterlogged soils, but as mentioned above, in the small foliage forests of the studied region where soil is too dry, only small-sized $O$. lacteum individuals are found, whereas more humid habitats (floodplains) are inhabited by the large-sized form of the species (Shehovcov, Ermolov, et al., 2020). It was also found that the size of adult $O$. lacteum individuals correlates with soil humidity (Ermolov, unpublished data), and a thick humus horizon ensures the presence of this species, since it is its main habitat and food source (Chekanovskaja, 1960; Perel', 1979). In more acidic, but also more humid habitats, $A$. c. caliginosa is found, while in dry forests with slightly acidic soil, only E. n. pallida is found, which is apparently able to survive in soils with low moisture content and a shallow humus horizon.

\section{CONCLUSION}

In pine forests and small foliage forests of the forest-steppe $\mathrm{Ob}$ region of Novosibirsk area, the species composition of earthworms is largely similar, but the total population density of worms is noticeably higher in small foliage forests. In most habitats, a significant proportion of the population consists of middle-soil-layer endogeic earthworms, and only in one case (small foliage forest in the vicinity of Morozovo), upper-soil-layer endogeic earthworms were predominant. Also, in some forests, the proportion of epigeic and epi-endogeic earthworms is high.

The deadwood studied in the forests was divided into three groups, depending on the predominant living forms of earthworms. Deadwood was most often dominated by epigeic earthworms, while in the fewest number of cases endogeic earthworms were present there. But with the same ratio of living forms of earthworms, deadwood within 
the same group can significantly differ in species composition.

The study confirmed that in forest ecosystems, soil humidity is the most significant factor for earthworms, especially for epigeic and epi-endogeic living forms. For the endogeic earthworms, the thickness of the humus horizon is also important.

Morphometric analysis of external morphological features provided rationalization for the identification of largesized and small-sized forms of the Eisenia $n$. nordenskioldi subspecies. Small-sized forms of this subspecies are typical epi-endogeic earthworms that inhabit the soil and deadwood. The large-sized form might belong to anecic worms.

The study provides initial data on the population of earthworms in the forest ecosystems of the forest-steppe $\mathrm{Ob}$ region of Novosibirsk area. In the future, it is planned to conduct more detailed studies of each type of forest, paying special attention to pine

\section{REFERENCES}

Akkumuljacija ugleroda $v$ lesnyh pochvah $i$ sukcessionnyj status lesov (Carbon accumulation in forest soils and forest succession status), Moscow: Tovarishhestvo nauchnyh izdanij KMK, 2018, 232 p.

Ashwood F., Vanguelova E.I., Benham S., Butt K.R., Developing a systematic sampling method for earthworms in and around deadwood, Forest Ecosystems, 2019, Vol. 6, No. 33, pp. 1-12.

Atlas Novosibirskoj oblasti (Atlas of the Novosibirsk region), Moscow: Roskartografija, 2002, 56 p.

Boeskorov V.S., Ekologicheskie uslovija obitanija dozhdevogo chervja Eisenia nordenskioldi, Eisen v merzlotnyh pochvah Jakutii. Avtoref. diss. kand. biol. Nauk (Ecological conditions of the earthworm Eisenia nordenskioldi, Eisen in permafrost soils of Yakutia. Extended abstract of candidate's thesis), Ulan-Udje: IOiEB SO RAN, 2004, 24 p.

Byzova Ju.B., Dyhanie pochvennyh bespozvonochnyh (Respiration of soil invertebrates), Moscow: Tovarishhestvo nauchnyh izdanij KMK, 2007, 328 p. forests and mixed forests, since they are home to earthworm species that have a limited range and are confined exclusively to the Asian part of Russia.

\section{ACKNOWLEDGEMENTS}

The author would like to express profound gratitude to the postgraduate student of the Department of General Biology and Ecology of NSU Maria Nikitichna Kim-Kashmenskaja for numerous consultations and support at the main stages of the work; to Professor Mihail Georgievich Sergeev and senior lecturer Vladimir Vladimirovich Molodcov (NSU, Department of General Biology and Ecology) for their mentorship, understanding, assistance in organizing the study, technical and scientific advice on data processing and consulting on organizational issues, as well as to the reviewers for valuable advice and just criticism.

State assignment CEPF RAS No. AAAAA18-118052590019-7.

Chekanovskaja O.V., Dozhdevye chervi i pochvoobrazovanie (Earthworms and soil formation), Moscow, Leningrad: Izd-vo AN SSSR, 1960, 208 p.

Ermolov S.A., Faunisticheskoe raznoobrazie i jekologija dozhdevyh chervej $\mathrm{v}$ biotopah rechnyh dolin lesostepnogo Priob'ja (Faunal diversity and ecology of earthworms in the biotopes of river valleys in the forest-steppe $\mathrm{Ob}$ ), $56^{\text {th }}$ International Scientific Studet's Conference ISSC 2018, Novosibirsk, 22-27 Aipril 2018, Novosibirsk: 2018, p. 155.

Ermolov S.A., Osobennosti raspredelenija zhiznennyh form dozhdevyh chervej (Lumbricidae) lesostepnogo Priob'ja (Features of distribution of earthworms life forms (Lumbricidae) in the forest-steppe Ob region), Nauchnye osnovy ustojchivogo upravlenija lesami (Scientific foundations of sustainable forest management), Moscow, 30 October-1 November 2018, Moscow: CJePL RAN, 2018a, pp. 43-45.

Ermolov S.A., Biotopicheskoe raspredelenie dozhdevyh chervej (Oligochaeta, Lumbricidae) $\mathrm{v}$ malyh rechnyh dolinah lesostepnogo Priob'ja (Biotopical distribution of earthworms (Oligochaeta, 
Lumbricidae) in small river valleys of the forest-steppe $\mathrm{Ob}$ region), Russian Journal of Ecosystem Ecology, 2019, Vol. 4, No. 2, pp. 1-18.

Ganin G.N., Strukturno funkcional'naja organizacija soobshhestv mezopedobiontov juga Dal'nego Vostoka Rossii (Structural and functional organization of mesopedobionts communities in the South of the Russian Far East), Vladivostok: Dal'nauka, 2013, $380 \mathrm{p}$.

Geraskina A.P., Dozhdevye chervi (Oligochaeta, Lumbricidae) okrestnostej pos. Dombaj Teberdinskogo zapovednika (Severo-zapadnyj Kavkaz, KarachaevoCherkessija) (Earthworms (Oligochaeta, Lumbricidae) the surrounding area of the Dombai of the Teberdinsky reserve (NorthWestern Caucasus, Karachay-Cherkessia), Trudy Zoologicheskogo instituta RAN, 2016, Vol. 320, No. 4, pp. 450-466.

Geraskina A.P., Ekologicheskaja ocenka dinamiki kompleksa dozhdevyh chervej (Lumbricidae) $v$ hode vosstanovitel'nyh sukcessij (Ecologicall assessment of the earthworms (Lumbricidae) complex dynamics in the course of regenerative successions), Smolensk: SGMU, 2016a, $149 \mathrm{p}$.

Geraskina A.P. The population of earthworms (Lumbricidae) in the main types of dark coniferous forests in Pechora-Ilych Nature Reserve, Biology Bulletin, 2016, Vol. 43, No. 8, pp. 819-830.

Geraskina A.P., Problemy kolichestvennoj ocenki i ucheta faunisticheskogo raznoobrazija dozhdevyh chervej $\mathrm{v}$ lesnyh soobshhestvah (Problems of quantification and accounting faunal diversity of earthworms in forest communities), Russian journal of ecosystem ecology, 2016c, Vol. 2, No. 2, pp. 1-9.

Golovanova E.V., Knjazev S.Ju., Karaban K., Est' li preimushhestva u aborigennogo vida dozhdevyh chervej po sravneniju s vidami vselencami v Zapadnoj Sibiri? (Are there advantages of native species of earthworms compared to the types of the invided species in Western Siberia?), XVIII Vserossijskoe soveshhanie po pochvennoj zoologii (XVIII All-Russia Meeting of Soil
Zoology), Moscow, 22-26 October 2018, Moscow: 2018, pp. 60-61.

GOST 28268-89 (Soils. Methods for the determination of moisture, maximum hygroscopic moisture and humidity sustainable wilting plants), Moscow: Standartinform, 2006, 14 p.

Holdsworth A.R., Frelich L.E., Reich P.B., Litter decomposition in earthworminvaded northern hardwood forests: Role of invasion degree and litter chemistry, Ecoscience, 2008, Vol. 15, No. 4, pp. 536544.

Kim-Kashmenskaja M.N., Fauna dozhdevyh chervej (Oligichaeta, Lumbricidae) dolina r. Berd' v Prisalair'e (Fauna of earthworms (Oligochaeta, Lumbricidae) of the Berd river valley in Prisalairye), Bioraznoobrazie: global'nye i regional'nye processy (Biodiversity: Global and Gegional Processes), Ulan-Udje, 23-27 June 2016, Ulan-Udje, 2016, pp. 242-243.

Krylova L.P., Akulova L.I., Dolgin M.M., Dozhdevye chervi (Oligochaeta, Lumbricidae) Taezhnoj zony respubliki Komi (Earthworms (Oligochaeta, Lumbricidae) of the Taiga zone in Komi Republic), Syktyvkar, 2011, 104 p.

Metody pochvenno-zoologicheskih issledovanij (Researching methods of soil zoology), Moscow: Nauka, 1975, 281 p.

Mugako A.L., Priroda Novosibirskoj oblasti (Nature of the Novosibirsk region), Novosibirsk: Novosibirskij gosudarstvennyj kraevedcheskij muzej, 2008, 40 p.

Musienko I.E., Ocenka vidovogo raznoobrazija semejstva Lumbricidae $\mathrm{V}$ Tashtagol'skom rajone Gornoj Shorii (Assessment of the Lumbricidae species diversity in the Tashtagolsky district of Gornaya Shoria), $57^{\text {th }}$ International Scientific Studet's Conference ISSC 2019, Novosibirsk, 14-19 Aipril 2019, Novosibirsk: 2019, p. 25.

Penev L.D., Vasil'ev A.I., Golovach S.I., Kvavadze E.Sh., Vdovoj sostav i klassifikacija gruppirovok dozhdevyh chervej (Oligochaeta, Lumbricidae) dubrav russkoj ravniny (Species composition and classification of earthworm groups (Oligochaeta, Lumbricidae) in Russian 
plain oak forests), Zoologicheskij zhurnal, 1994, Vol. 73, No. 2, pp. 23-37.

Perel' T.S., Dozhdevye chervi (Oligochaeta, Lumbricidae) v lesah Zapadnogo Sajana (s opisaniem novogo vida) (Earthworms (Oligochaeta, Lumbricidae) in the forests of Western Sayan (with a description of a new species), Zoologicheskij zhurnal, 1994, Vol. 73, No. 2, pp. 18-22.

Perel' T.S., Rasprostranenie $i$ zakonomernosti raspredelenija dozhdevyh chervej fauny SSSR (Distribution and distribution patterns of earthworms fauna in the USSR), Moscow: Nauka, 1979, 272 p.

Perel' T.S., Zavisimost' chislennosti i vidovogo sostava dozhdevyh chervej ot porodnogo sostava lesonasazhdenij (Dependence of the quantity and earthworm's species composition on the species composition of forest plantations), Zoologicheskij zhurnal, 1958, Vol. 37, No. 9, pp. 1307-1314.

Perel' T.S., Zhiznenye formy dozhdevyh chervej (Lumbricidae) (Earthworm's (Lumbricidae) living forms), Zhurnal obshhej biologii, 1975, Vol. 36, No. 2, pp. 189-202.

Pochvennaja karta Novosibirskoj oblasti (Soil map of the Novosibirsk area), Novosibirsk: Izd. IPA SO RAN, 2007.

Rapoport I.B., Sezonnaja aktivnost' dozhdevyh chervej (Oligochaeta, Lumbricidae) pojasa shirokolistvennyh lesov kabardino-balkarskogo gosudarstvennogo vysokogornogo zapovednika i prilegajushhih territorij (Central'nyj Kavkaz) (Seasonal activity of earthworms (Oligochaeta, Lumbricidae) in broadleaved forests belts of the KabardinoBalkar state high-mountain reserve and adjacent territories (Central Caucasus), Izvestija samarskogo nauchnogo centra
Rossijskoj akademii nauk, 2010, Vol. 12, No. 1(5), pp. 1345-1348.

Shashkov M.P., Fauna dozhdevyh chervej (Lumbricidae) zapovednika "Kaluzhskie zaseki" (The earthworms (Lumbricidae) fauna of "Kaluzhskie Zaseki" nature reserve), Trudy gosudarstvennogo prirodnogo zapovednika "Kaluzhskie zaseki”, Issue 1, 2003, pp. 90-93.

Shehovcov S.V., Bazarova N.Je., Berman D.I., Bulahova N.A., Golovanova E.V., Konjaev S.V., Krugova T.M., Ljubechanskij I.I., Pel'tek S.E., DNKshtrihkodirovanie: skol'ko vidov dozhdevyh chervej zhivet na juge Zapadnoj Sibiri? (DNA barcoding: how many earthworm species live in the South of Western Siberia?), Vavilovskij zhurnal genetiki i selekcii, 2016, Vol. 20, No. 1, pp. 125-130.

Shehovcov S.V., Ermolov S.A., Derzhinskij E.A., Polubojarova T.V., Laricheva M.S., Pel'tek S.E., Geneticheskaja i razmernaja izmenchivost' Octolasion tyrtaeum (Lumbricidae, Annelida) (The genetic and dimensional variability of Octolasion tyrtaeum (Lumbricidae, Annelida)), Pis'ma $v$ Vavilovskij zhurnal genetiki $i$ selekcii, 2020, Vol. 6, No. 1, pp. 5-9.

Vjen Rajzin Dzh., Klassifikacija i klaster (Classification and cluster), Moscow: Mir, 1980, $390 \mathrm{p}$.

Vorob'eva L.A., Ladonin D.V., Lopuhina O.V., Rudakova T.A., Kirjushin A.V., Himicheskij analiz pochv. Voprosy $i$ otvety (Chemical analysis of soils. Questions and answers.), Moscow, 2012, 186 p.

Vsevolodova-Perel' T.S., Dozhdevye chervi fauny Rossii. Kadastr $i$ opredelitel' (Earthworms of the fauna of Russia. Inventory and identification guide), Moscow: Nauka, 1997, 102 p.

Reviewer: candidate of Biological Sciences, Senior Research Officer Geraskina A.P. 